\title{
公共政策を巡るドミナント・ストーリーの 中学校公民教科書における記述内容の検証
}

\author{
田中 皓介 1 ・神田 佑亮 ${ }^{2} \cdot$ 藤井 聡 $^{3}$ \\ 1 学生会員 京都大学大学院 都市社会工学専攻（†615-8540 京都府京都市西京区京都大学桂 4) \\ E-mail: tanaka@trans.kuciv.kyoto-u.ac.jp \\ 2 正会員 京都大学大学院准教授 都市社会工学専攻（干615-8540 京都府京都市西京区京都大学桂 4) \\ E-mail: kanda@trans.kuciv.kyoto-u.ac.jp \\ 3 正会員 京都大学大学院教授 都市社会工学専攻（干615-8540 京都府京都市西京区京都大学桂 4) \\ E-mail: fujii@trans.kuciv.kyoto-u.ac.jp
}

\begin{abstract}
現在および将来の日本のために行われる公共事業をはじめとした公共政策を，適切に計画・実施するた めには，社会についての適正な現状認識が不可欠である。一方で，政策決定に大きな影響力をもつ国民世 論は，教育の影響を受けることが想定される。そのため，適切な事業の円滑な実施に向け，教育の現状を 明らかにすることに意義があろう。そうした認識のもと本研究では，日本の現状を巡る認識について，現 代社会についての見方や考え方の基礎を養うことを目的とする中学校公民の教科書を対象に，関連する記 述を網羅的に抽出し，既存の文献を参考にしつつ，その内容について考察を行った．分析の結果，公共事 業に関し，直接的に印象的かつネガティブな内容が掲載されている点，財政についての知識教育が現実と 乘離している点などの問題が明らかとなった.
\end{abstract}

Key Words : public works, mass media, public communication, textbook

\section{1. はじめに}

公共事業は社会インフラを整備し，自然災害に対して 安全・安心な国土や良質な生活環境を構築し，さらには 活発な経済活動を支える極めて重要なものである．特に 近年では，老朽化したインフラの更新や，災害に対して 強くしなや力な国土の形成を目指寸国土強鞋化政策の推 進など，公共事業の必要性も高まりつつある.

一方でそうした公共事業に対しては，主権者である国 民の世論が，決定的に重要な影響をもつことが想定され る。しかし田中・神田（2013）1)は国民世論の公共事業 に対する否定的なイメージの定着を示唆し，さらに田中 ら (2013） 2)は，マスメディアの否定的な報道の存在可 能性も示唆している. そのような批判的な世論を受けて, 公共事業の無駄が削減され，事業が効率化されたという 面があろうことは否定しない. しかしそれ以上に，2000 年代の, 他の先進国でも例を見ない様な公共事業の急激 な削減は，真に必要な事業の削減や遅延をもたらしてい るのではないかと眯念する声もある3)。こうした状況の 中で，逆風世論とも言うべき，世論の問題について取り 組むことは，必要な社会資本整備を円滑に実行するため には不可欠である.
国民世論については，マスメディアの影響は無視でき ないものと考えられ，特にテレビや新聞などのメディア 報道の及ぼす影響がしばしば指摘されている4). 一方で, 学校教育における教科書も対象はある程度限られてはい るものの，不特定多数を対象にした出版物という意味で はマスメディアの一種であるともいえよう。その中でも 特に中学校の教科書は, すべての国民を対象としており, その内容に基づき教育が行われていることを考えると， 人々の知識形成段階において与えられるその情報は，将 来にわたって人々の意識に影響を及ぼし続ける可能性も 考えられる.

土木分野において学校教育の重要性の認識は高まって いる．例えば交通・環境の分野では，谷口ら（2002）5) は交通行動変容のはたらきかけに対し, 大人よりも子ど もにおいて，その効果が継続していたことを報告するな ど，教育に着目した多くの実践的な研究報告がなされて いる6)。 あるいは，東日本大震災において徹底した防災 教育が多くの人命を救った，いわゆる「釜石の奇跡」と 呼ばれる事例7)，教育の重要性を示す事例と言える.

このように，土木に関連する分野の，特に実践的な研 究の場において学校教育の重要性が認知され，教育に焦 点を当てた研究や取り組みが進められており，国民意識 
の問題に取り組むに当たって, 学校教育を対象とするこ とには一定の意義があるものと考えられる.

そうした中，公共事業を巡る教科書内容については， 森田（2013） ${ }^{8)}$ の研究報告がある. 森田は「国土学」9)の 考え方，つまり，我々が国土一働きかけることで，国土 から恵みを享受しており，現在の豊かな生活はそうした 歴史の積み重ねの賜物であるとする考え方が，中学校の 社会科教科書においてどのように取り扱われているのか を分析している.

その中で，地理的分野の教科書においては，高速道路 をはじめとする交通インフラの整備効果について図表を 用いて説明し，国土への働きかけの効果や歴史が，それ ぞれの地方ブロックごとに詳しく説明されていると指摘 している.

また，公民的分野の教科書では，社会資本整備の説明 や，不況（デフレ）時の財政政策についての記述が見ら れる一方で,「産業基盤としての社会資本はかなり整備さ れた」とする教科書が少なくないことなどを指摘してい る.

以上の様に, 森田 ${ }^{8)}$ は公共事業の必要性や意義そのも のに関する記述の検証を行っているものの，それだけで なく, 公共事業への間接的な影響も考え, より広く現代 の社会状況に関する教育内容について検証を行うことも 必要であると考えられる，というのも，公共事業を巡る 批判では例えば,「危機的な日本の財政状況では, 公共事 業を行う余裕はないりいった財政問題としての批判や,

「人口減少の避けられない日本では，今あるインフラを 活用寸るだけで十分である」といった日本の現状や将来 展望を踏まえた否定的な意見も想定される。つまり，公 共事業そのものの意義に対する是非のみならず，それを 取り巻く現代の日本あるいは世界の状況についての認識 が，公共事業の是非に間接的とはいえ無視できない影響 力を持つことが想定されるのである.

こうした現状を踏まえると，学校教育の中でも「現代 社会についての見方や考え方の基礎を養うとともに，社 会の諸問題に着目させ，自ら考えようとする態度を育て る」(新学習指導要領) ことを目的とした中学校の公民的 分野の内容は，公共事業を巡る世論に大きな影響を及ぼ し得るものである.

以上より，公共事業に対寸る国民の認識を，事実から 乘離したイメージや先入観ではなく, 客観的な事実に則 したものにしていくにあたっては, 公共事業そのものの みならず，それに関連する社会状況についての，教科書 の内容を分析・検証しておく必要があると考え, 本研究 ではその現状を明らかにすることを目的とする.

\section{2. 分析の方法}

\section{(1) 分析の概要}

本研究では, 公共事業に関連する中学校の教科書の内 容を検証する．そのためにまず，既存の研究を参考に， 公共事業に直接・間接に関連が想定される, 現代社会を 巡る複数の論点を設定する. その上で, 各教科書からそ れらの論点に関連する記述を網羅的に抽出する.そして, 抽出した記述内容について, 特に図や写真を用いた印象 的な内容や，事実を誤認させかねないような内容を中心 に, 第 2 章(3)節で詳しく述べる複数の観点から, その記 述を検証・考察する. そうして, 現在使われている教科 書ないしは現代の教育内容の状況の一端を明らかにする ことを目指す。

\section{(2) 分析の対象}

本研究では中学校の社会科の公民的分野の教科書を対 象とする. 我が国における学校の教科書は, 民間発行者 が学習指導要領に基づいて著作・編集し, 文部科学大臣 の検定を経てはじめて, 教科書として使用される資格が 与えられる10)。なお，どの教科書を利用寸るかの権限は 所管の教育委員会あるいは学校長にあり, 国の負担で全 児童生徒に対して無償で供与されるものである ${ }^{10)}$.

本研究で対象とする教科書は, 2008 年の学習指導要領 改訂を受け, 2011 年 3 月に検定に合格し, 2012 年 4 月か ら使用が開始されている中学校の公民的分野の教科書で ある. なお， 2011 年 3 月の検定に合格した公民的分野の 教科書は, 東京書籍, 日本文教出版, 教育出版, 帝国書 院, 育鵬社, 清水書院, 自由社の計 7 社が発行しており, 本研究ではそれら 7 社全ての教科書についての分析, 考 察を行う。

\section{(3) 論点の設定}

本研究では特に, 公共事業のみならず, それへの関連 が想定される社会状況についても焦点を当てて分析を行 うが，その際，ストーリーないしはナラティブ（物語） を手掛かりに，社会状況についての認識を巡る教科書内 容の検証を行う。

物語は人文社会科学の様々な分野で取り上げられてき たが, 本研究では特に, 臨床心理の分野での実践に着目 する，それは，クライアントが持っている自己物語（自 分自身についての認識) について，セラピストが会話を 通じてその物語を脱構築し再構築することで, 心理的な 問題を解消するものである11).こうした，自己物語とし て支配的となっている物語はドミナント・ストーリーと 呼ばれるが，そうした物語は個人をめぐるミクロなレべ ルのみにとどまらず，社会全体を覆うようなマクロなレ ベルの物語も存在し, 社会の動向に大きな影響力を持ち 
得ることも指摘されている12). そして，マクロなレベル においても個人の心理療法と同様に，支配的な物語（ド ミナント・ストーリー) から別の物語 (オルタナティブ・ ストーリー) への転換は, 社会問題の解決において有用 である可能性が指摘されている13).

なお，ドミナント・ストーリーは必ずしも悪いもので はなく, それ以上遡る必要のない起点として, 日常世界 の複雑性を縮减するのに重要な役割を果たしているとも 考えられる一方で,「抑圧の道具」となりうることも指摘 されている ${ }^{12)}$ ，すなわち，ドミナント・ストーリーはあ る状況を支配している物語であり，それは，ある状況に

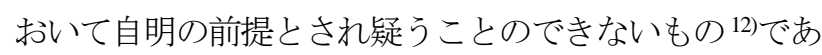
るがゆえに, 集団において特定のドミナント・ストーリ 一が強く共有されれば，そのストーリーに沿ったアウト プットの効率的な生産を可能にする一方で，それとは一 致しないアウトプットの生産が抑圧される事態が想定さ れる.もちろん，ドミナント・ストーリーに一致しない アウトプットに公的な意義がなければ，そうした状況に 何ら問題はないが，そうでない場合には，ドミナント・ ストーリーの共有という事態が公益を著しく損失させる 可能性も懸念されるのである.

加えて，原則的に全ての国民を対象としている教科書 の内容が，そうしたドミナント・ストーリーを背景とし たものであれば，それは疑われることなく自明の前提と して将来世代に教育され，将来にわたってその認識はよ り広くより強固なものとなっていくことが想定される.

以上を踏まえれば，公共事業をはじめとする公共政策 の実施・計画にあたって求められる，事実に即した客観 的な現状認識を可能にするためにも，社会的に共有され たドミナント・ストーリーに着目し，その上で長期にわ たる影響の想定される教科書を対象として分析を行うこ とに一定の意義を見出せよう.

そうした中で，藤井 ${ }^{14} は$ 公共政策論を巡って，テレビ や新聞などのマスコミや一般国民，さらには知識人の間 に共有されている可能性の考えられるドミナント・スト 一リーのうち, 公益の観点から問題をはらんでいる可能 性が考えられるドミナント・ストーリーを列挙している. さらにそれらが共有されることによる不利益の可能性を 論ずるとともに, より望ましい代替的な物語, すなわち オルタナティブ・ストーリーのあり方を論じている.

本研究では, その論議を参考に, それらのドミナント・ ストーリーの中で公共事業の実施に直接・間接に関わる 可能性の考えられる物語として, 「公共事業不要論」,「日 本財政破綻論」,「右肩下がり宿命論」,「外に打って出る しかない論」「地方分権化の時代だ論」の 5 つを想定す る. なお，これらの物語は必ずしも公共事業や土木事業 に直接かかわるものではない，とはいえ，公共事業が財 政面から批判されることも頻繁1)であり，「日本の財政破
綻」についての認識は大きな影響力を持ち得るものであ る. また, 「右肩下がり宿命論」,「外に打って出るしかな い論」,「地方分権化の時代だ論」の3つについては, 現 在ないしは今後の日本をとりまく社会的状況に関するも のであり，公共事業が未来に向けての投資の意味を持つ 以上は，そうした現在および今後の日本の在り方につい ての認識は，公共事業の是非に大きく影響することが考 えられる. それでは以下に各物語の詳細と, それが共有 されることで生じる可能性のある弊害について, 藤井 ${ }^{14)}$ の指摘を参考に説明する.

\section{a) 公共事業不要論}

まず，公共事業そのものに直接関わる以下の様な物語 である.

「政府が行う公共事業には無駄が相当程度含まれてお り，予算を削減していっても無䭾な公共事業が減るだけ であるから，公益は損なわれない。むしろ，削減された 予算を用いて他の事業ができることから，公共事業の削 減は公益を増進させるだろう.」

こうした物語がドミナント・ストーリー化していなけ れば，今日ほどに公共事業が削減され続けるという事態 を招くことはなかったであろうと考えられる.

\section{b) 日本財政破綻論}

公共事業の批判の論点の一つに財政の問題があり, 日 本の財政について共有される物語の如何によっては, 公 共事業実施に対して大きな影響を及ぼし得ると考えられ る. そうした財政の問題については，以下の様な物語が 人々の間に共有されていると考えられる.

「これからさらに累積債務が増え続ければ近い将来, 金融市場における国債の長期金利が上昇（国債価格が低 下）し始める. そしてその内，国債が “投げ売り”され はじめ, 国債価格が暴落し金利が急上昇することを通し て，政府の資金調達が不能となるばかりか，その金利の 支払いさえも不可能となり，例えばギリシャ等がそうな ったように日本政府が破綻することとなるだろう．だか ら国債発行をこれ以上増や寸わけにはいかない.」

こうした物語が強く共有された状況においては, 財政 の破綻を過度に恐れるあまり, 国債発行は限定的になり, 震災の復旧・復興であっても事業資金が十分に賄えず, 事業の実施規模が限定的になるばかりか, デフレ不況対 策や大きな経済的なショックに対する財政出動の規模も 限定的になり，適切な政策実施の妨げとなる事態が考え られる。

\section{c）右肩下がり宿命論}

また，日本の現状や将来の展望を巡る議論の前提とし て以下の様な物語が共有されていると考えられる.

「我が国は急激な少子高齢化の時代を迎えている，そ の結果，人口が減り，それを根本的な原因として日本の 活力そのものが低迷していく，もう高度成長期のような 
右肩上がりの時代なのではなく, 右肩下がりの時代なの だ.」

こうした物語が共有された社会では，人口が減少する 中でインフラの新規建設は不要であり, むしろそうした 無駄な事業によって生じる借金や維持更新費という負の 遺産を残してしまうという認識となり，公共事業に対し て否定的となることが考えられる．とはいえ，こうした 認識が共有されるほどに, インフラ整備をはじめあらゆ る政策は，より一層人口減少社会に向けたものとなり， そうした状況がますます人口減少，活力低下を促進する という負の循環に陥りか叔ないのである.

\section{d) 外に打って出るしかない論}

上記の「右肩下がり宿命論」を運命と捉えることによ って, 次の様な物語も共有されていくこととなる.

「少子高齢化の右肩下がりの時代には，国内にはマー ケットが無くなってしまった. グローバル化時代の今, 外に打って出るしかない

こうした物語が広く共有されれば，国の政策は外向 き・外需志向になる一方で, 内需は軽視される傾向とな っていく.そうなれば, 国内事業者はないがしろにされ, 国内のインフラ整備の優先度は下がり, 国内で生活する 多くの国民の不利益となりかねない.

\section{e) 地方分権化の時代だ論}

さらには，「右肩下がり」や「海外に出るしかない」と 同様に, 時代の不可避な趨勢と捉えられているものに「地 方分権化」が挙げられる.

「中央集権では，地域の実情を十分に勘案した行政少 一ビスを提供することが出来ない，したがって，地域の 実情にあわせた行政サービスを提供していくためにも地 方分権が必要であり, これからは全て, 分権化していく のが時代の流れだ．だから，基本的には中央政府をより 小さくした方がいいし，基本的には中央と地方との間で の権限の配分を考える際には，地方を優先することが得 策だ.」

もちろん，他のドミナント・ストーリー同様にこうし た物語にも全く理がないわけではない，行政の仕事には 地方分権化が望ましい項目もあれば，中央集権化が望ま しい項目もあろうことは間違いないと考えられる. しか し過度にこうした物語が共有されれば，例えば公共事業 については地域の事情のみが考慮され，より大きな視点， すなわち地域間の連携や国家規模で適切と考えられるイ ンフラ整備の実施を困難にし，公益を損ねることにもな りかねない。

以上で想定した $5 つ の$ 物語は，その物語が人々に広く 共有されることによって，直接，間接に公共事業実施に 影響を与える可能性が考えられるものである. なお，以 上のそれぞれのドミナント・ストーリーの問題点や，代 替寸る物語（オルタナティブ・ストーリー）などの詳説

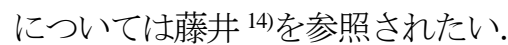

本研究では上述の 5 つの物語を想定した上で, 学習指 導要領を参考にし, から, 教科書が中学生向けであるこ とも踏まえつつ，以下の様な観点を中心に教科書の記述 内容を取り上げることとする.

まず,「公共事業不要論」については公共事業に対する ネガティブな記述に加え，その実施主体である行政や政 府の無駄や非効率に関する記述についても取り上げる.

「日本財政破綻論」については, 中学生向けの教科書 において，必ずしも上記で想定した物語のような論理的 説明がなされているとは考え難いため, より単純化した 表現として, 財政赤字や国債残高の深刻さを強調する記 述を取り上げる.

「右肩下がり宿命論」及び「外に打って出るしかない 論」については，その前提にあると考えられる少子高齢 化やグローバル化についての現状やその社会的影響, 特 に経済活力に関する記述を取り上げる.

「地方分権化の時代だ論」については，その制度を正 しく理解するために重要と考えられる, 中央集権と地方 分権についてのそれぞれの意義や課題についての記述を 取り上げる.

以上の様に教科書の内容を検証し，それぞれの物語を 背景としていると考えられる表現や，あるいはそれらの 物語の認識を促進するような記述内容の存在を明らかに していく.人々に共有されている物語, すなわちドミナ ント・ストーリーを，より望ましい代替的な物語へと変 容するためにはまず，こうした現状把握が重要な意義を 持つと考えられるのである.

\section{3. 結果と考察}

対象とする各教科書から，上述の観点によって抽出し た記述内容を付録-1～付録-5 に示す．以下ではそれぞれ のドミナント・ストーリーごとに，その記述内容につい て考察を行う。なお，各ドミナント・ストーリーについ て, 各教科書に見られた論点を整理したものを表-1〜表 -5 に示寸. 表中の数字は該当する記述のある頁であるが, 複数該当する場合は主要と考えられる頁を挙げている.

また, 以下では教科書から引用した記述については『』 で表している。

\section{（1）「公共事業不要論」に関する教科書内容についての 考察}

まず，公共事業そのものの意義や役割など肯定的な論 点については, 森田（2013） 8)の報告に詳しいためそち らを参照されたい。，一方で, 公共事業不要論に関する教 科書内容について, 多くの教科書では直接的に公共事業 
を批判するような内容は必ずしも見られないが，とりわ け印象的な内容が見られたのが日本文教出版であり，複 数の新聞記事を掲載しながら説明している. まず,『公共 事業の見直しを報じる新聞』(p.166) と題して，事業仕 分けによる 200 億円事業の廃止及び，八ツ場ダムの建設 中止を報じる 2 つ新聞記事を掲載し,『公共事業のあり 方や要不要をめぐって, 費用と効果の面で議論がさかん です.』と説明を加えている.さらに，『独占禁止法違反 を報じる新聞』(p.139) と題して，『談合，113 社に排除 勧告. ゼネコン暗躍，瘉着深く』と報じる新聞記事を掲 載しており，公共事業に対してネガティブな内容が掲載 されている。

次に帝国書院の教科書では, p.163の欄外には, 公共事 業に対する賛否両論を併記し，問題提起を行っている. その内容は，賛成意見として『道路や公園が増えるのだ から，生活が便利になる．公共事業は，働く場を提供す る.』と説明し，反対意見として『少子高齢化の現在，公 共事業はなるべく減らして，その分社会保障を充実させ るべきだ．無䭾な公共事業に使うお金があるなら，その 分減税すべきだ.』と説明している. 当該記述内容は, 無 駄な公共事業の存在を示唆する内容であることに加え, 賛成意見が事実情報の提供に留まるのに対し，反対意見 は「〜すべきだ」と，主張的な表現がなされており，反 対意見について強い印象を与えか福ない記述内容である と考えられる.

一方で育鵬社は，財政に関連した批判的な内容が見ら れる.『財政赤字』(p.138) という項において，『利用者 のほとんどいない厚生施設などの無駄な社会資本を建設 するようなことは，さけなければなりませんし，公債の 発行は慎重に行う必要があります.』という記述がある. 加えて, 『地方財源の再建』(p.139) という項において約 1 頁を割いて，財政再建の成功事例として大阪府を取り 上げ，その中で以下の様に説明している.『道路や河川の 整備など, 国の直轄事業の費用負担や, 府の巨額プロジ エクトの負債, そして 1970 年代の府政により, 社会保障 費とそれにともなう人件費の増大など，大きな負債を抱 えていたため, 公債を発行し続けてきました. そこで, 大阪府は職員給与を都道府県最低水準まで引き下げ，建 設事業費を大幅に削減しました．また市町村補助金の削 減なども行い，歳出を抑えることにより財政を再建しま した.（中略）いかに無䭾な支出をおさえるかが，財政改

表-1 公共事業不要論の論点の整理

\begin{tabular}{|c|c|c|c|c|c|c|c|}
\hline 「公共 & \begin{tabular}{|l} 
東京 \\
書籍
\end{tabular} & $\begin{array}{l}\text { 日本 } \\
\text { 文教 }\end{array}$ & $\begin{array}{l}\text { 教育 } \\
\text { 出版 }\end{array}$ & \begin{tabular}{|l} 
帝国 \\
書院
\end{tabular} & \begin{tabular}{|l|} 
育鵬 \\
社 \\
\end{tabular} & $\begin{array}{l}\text { 清水 } \\
\text { 書院 }\end{array}$ & \begin{tabular}{|l} 
自由 \\
社
\end{tabular} \\
\hline$\pi$ & & P.166 & & P.163 & P.138 & & \\
\hline 非 & P. 80 & P.104 & P. 91 & P.88 & P.117 & & \\
\hline & .132 & P.166 & P.146 & P.162 & P.136 & P.126 & .138 \\
\hline $\begin{array}{c}\text { 定的 財政 } \\
\text { 整借 }\end{array}$ & P.132 & P.175 & $\begin{array}{l}\text { P.153 } \\
\text { P } 165\end{array}$ & & P.140 & P.126 & \\
\hline
\end{tabular}

革の出発点といえるでしょう.』

ここでは, 財政再建のための複数の要素が挙げられて はいるものの，インフラ整備のための建設事業費が無駄 な支出の主要なものとして説明されている.

さらに育鵬社の教科書では，『さまざまな行政改革』 （p.91）と題し，『例えば，国が鉄道を運営していると， なぜ無駄がでてしまうのか考えてみましょう』との記述 が，また『公共事業の民営化』(p.117）と題するコラム においては,『公企業の経営は, 市場競争が制約され, 経 営不振や倒産への危機感がうすいため，非効率になるこ とがあります.』との記述がある。このように，育鵬社の 教科書には政府・行政の仕事の無駄や非効率を指摘する 記述内容が見られる. 同様の記述は東京書籍にも見られ, 『国や地方公共団体は企業のように倒産することがあり ませんから，仕事が非効率なものになりがち』(p.80) と 説明されている.

また，公共事業の関係者として重要な公務員の仕事に ついて，特に「たてわり行政」の説明が 5 社の教科書 で見られる. それぞれの説明を見ると, 自由社の『細分化 された行政組織の相互の意思疎通がなされず』(p.94)とい う説明に比心゙,『国や地方公共団体全体よりもそれぞれの 部門の利益を重視する傾向』(東京書籍, p.81), 『自分の 所属する行政組織のせまい利益を優先しがちです』(日本 文教出版，p.104）、『それぞれの省庁の利益を優先させる』 (教育出版, p.91)，『なわばり争いが生まれている』(帝国書 院, p.88)という 4 社の説明は, 人・組織の利己的側面を強 調した表現であり, 受ける印象は随分とネガティブなもので ある可能性が考えられる。

\section{（2）「日本財政破綻論」に関する教科書内容についての 考察}

まず，日本の財政に関する記述は， 7 社すべての教科 書において，国債の発行残高の推移グラフが掲載されて おり, 加えて国債の発行は将来世代に対する大きな負担 とする説明がなされている.

ここで，そもそも国債は建設国債と特例国債とに区別 されるが，近年の国債発行残高の増加の大きな要因とし ては，社会保障関係費の増加によって発行が増えた特例 国債の増加である。一方で，建設国債はそもそも 2000 年頃からほとんど増えていないだけでなく, 公共事業実 施のために発行される建設国債は，その投資によって作 られる橋や道路，ダムが，数十年から 100 年程度の将来 にわたっても恩恵をもたらすことから，その費用を将来

表-2 日本財政破綻論の論点の整理

\begin{tabular}{|c|c|c|c|c|c|c|c|}
\hline 「日本財政破綻論」 & \begin{tabular}{|l|l|} 
東京 \\
書籍 \\
\end{tabular} & \begin{tabular}{|l|} 
日本 \\
文教
\end{tabular} & \begin{tabular}{|l} 
教育 \\
出版 \\
\end{tabular} & $\begin{array}{l}\text { 帝国 } \\
\text { 書院 }\end{array}$ & \begin{tabular}{|l} 
育鵬 \\
社
\end{tabular} & \begin{tabular}{|l} 
清水 \\
書院
\end{tabular} & \begin{tabular}{|l|} 
自由 \\
社
\end{tabular} \\
\hline \multirow{2}{*}{$\begin{array}{c}\text { 肯定的国債残高の増加 } \\
\text { 将来への負担 }\end{array}$} & P.96 & P.163 & P.151 & P.164 & P.138 & P.131 & P.94 \\
\hline & P.131 & P.163 & P.151 & P.164 & P.138 & P.131 & P.95 \\
\hline 中立的 国債の種類説明 & 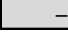 & & & & P.138 & & 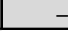 \\
\hline
\end{tabular}


世代と分担する意味をも持ち，これを単なる将来世代の 負債・負担と捉えることは，適切ではないのではないか と考えられる。

そうした中，国債の種類が区別されて説明がなされて いるのは, 育鵬社の教科書のみである. そこでは,『建設 国債…公共事業などを行うために発行. 特例国債…税収 不足を補うために発行.』(p.138) と区別されてはいるも のの, それでも国債の発行について, 『恩恵の多くを受け 取れるのは, 現在生活している私たちです.』と説明し, さらに『国債残高の増加は，将来世代に大きな負担を残 すことになります.』(p.138) という説明がなされている.

また，財政の問題についてとりわけセンセーショナル な記述として, 日本文教出版の教科書では, 『日本の人口 を 1 億 2500 万人として, 2010 年の国債残高から, 国民 1 人あたり約何万円の借金になるか, 計算してみましょう. 約 637 兆円 $\div 1$ 億 2500 万人 $=\square$ 万円』という記述がある

(図-1)。さらに, 教育出版の教科書では, 国債費につい て『一日当たりに支払われる国債費』と題した図を挿入 し，『1 日当たり約 590 億円. 1 時間当たり約 25 億円. 1 分当たり約 4100 万円. 1 秒当たり約 68 万円.』(p.151, 欄外）と記述している（図-1）.

この様な,「一人当たりの借金」として強調する表現や， 時間当たりの国債費の算出からは，国債の巨額さを強調 する以外の論理的な意味を見出し難く, 日本財政に対す る危機感を印象づける内容であるといえよう.こうした, 「国民が膨大な借金を抱いている」と強調する表現は, いたずらに不安を助長するだけであり，日本の財政に対 する正しい認知を妨げか叔いとの指摘もあり 15$)$, 現代 社会についての基礎知識を学ぶ場におけるこうした表現 は，不適切なものである可能性が懸念される。

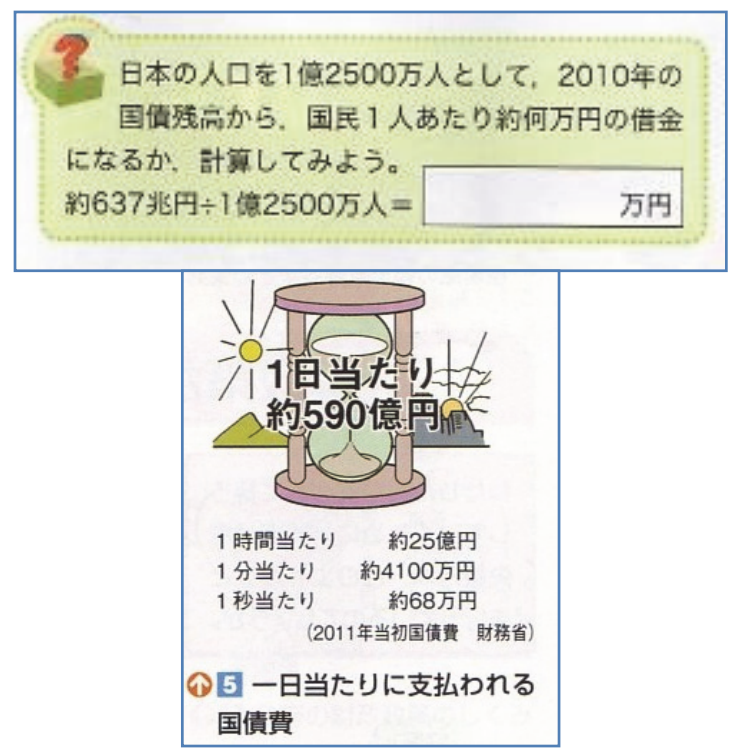

図-1 巨額な国債残高を強調する内容 (上: 日本文教出版(p.163), 下 : 教育出版(p.151))
一方で帝国書院の教科書では, 『報道から事実と意見を 区別する』(p.75) と題するコラムにおいて，『とても素 直に喜べない，新年度予算の成立にめどはついたが，財 政の先行きがますます不安だ. 一般会計総額 92 兆円は, 当初予算で過去最大. 新規国債発行額は税収を上回り 44 兆円にのぼる.借金中毒のような財政の姿がここにある.

(2010 年 3 月 3 日朝日新聞, 社説)』という朝日新聞の 社説を掲載している.この教科書では，この記事に対し て事実に当たる部分と筆者の意見に当たる部分を区別さ せるものとなっており，マスメディアと政治の関係を学 ぶ単元ではあるものの，「借金中毒」というネガティブな 表現が掲載されている.

また自由社の教科書の本文内で，『国家財政の基本は， 一家の家計と同じように 1 年間の収入と支出のバランス がとれていなければなりません.今日のわが国の財政は, 年間 40 兆円をこえる国債の発行による借入金に依存し ており，問題となっている状態です.』(p.95) という記 述がある.こうした国家の財政を家計に例える表現は分 かりやすい表現ではあるものの，そもそも，通貨発行権 を持つ国家の財政と，家計とはその性質が根本的に異な るものであり, 間違った認識を与えか祆ない内容である.

\section{（3）「右肩下がり宿命論」に関する教科書内容について の考察}

右肩下がり宿命論の前提には,「少子高齢化の進展」が 想定されるが，学習指導要領においては，公民的分野学 習の導入として，少子高齢化を現代日本の特色として理 解させ，社会への影響を気付かせることと規定されてい る. そのため少子高齢化の影響については，すべての教 科書において多くの分野と関連させた説明が見られる.

まず，少子高齢化に関連してすべての教科書で主題と なっているのは, 介護など福祉の問題, 寸なわち高齢者 を支えるための今後の社会制度問題についてであり，現 代日本の課題としての社会保障制度に対寸る認識を深め る内容となっている.

一方で，「働き手の減少による，社会活力の低下」を指 摘する様な記述が見られるのは, 日本文教出版, 帝国書 院, 育鵬社, 清水出版, 自由社であり, 各教科書の冒頭 部分で説明が見られる.

そうした中，特に少子高齢化を日本の経済活力につな げる詳しい記述が見られるのが, 育鵬社の教科書である. 『少子化による将来の労働力不足や個人消費の伸びなや

表-3 右肩下がり宿命論の論点の整理

\begin{tabular}{|c|c|c|c|c|c|c|c|}
\hline 「右肩下がり宿命論」 & $\begin{array}{l}\text { 東京 } \\
\text { 書籍 }\end{array}$ & $\begin{array}{l}\text { 日本 } \\
\text { 文教 } \\
\text { 出版 }\end{array}$ & $\begin{array}{l}\text { 教育 } \\
\text { 出版 }\end{array}$ & \begin{tabular}{|l} 
帝国 \\
書院
\end{tabular} & \begin{tabular}{|l} 
育鵬 \\
社
\end{tabular} & $\begin{array}{l}\text { 清水 } \\
\text { 書院 }\end{array}$ & $\begin{array}{l}\text { 自由 } \\
\text { 社 }\end{array}$ \\
\hline 人口減少予測 & P.12 & P.6 & P.9 & P.6 & P.20 & P.12 & $\overline{P .8}$ \\
\hline 月正叫 経済活力の低下 & - & P.203 & - & P.6 & P.106 & P.13 & P.8 \\
\hline 否定的 経済成長可能 & & P.203 & - & & P.150 & & \\
\hline
\end{tabular}


みなども日本の経済に影響を与えることが予想されま す.』（p.20）と説明しさらに，『1990年代に入ると，日本 の経済成長は長期にわたって停滞するようになりました 今は子どもの数が減少し，総人口に対する高齢者の割合 が高い少子高齢の時代をむかえています.』（p.106）と， 1990 年代からの経済の停滞要因を少子高齢化に求める ような説明となっている，一方で，経済についての章の 『日本経済のこれから』という項において,『日本は少子 高齢化によって人口が減少に転じていますが，経済成長 ができなくなるわけではありません。日本には，利用す れば高い価值を生み出す社会資本がたくさんあり，生産 に利用できる設備も，質・量ともに充実しています。こ れらをうまく使って技術革新をすすめ, 新たな価值をも つ財やサービスを生み出すことができます.』(p.150) と 説明がなされている，この様に，少子高齢化による経済 への影響はあるものの，人口減少下でも経済成長は可能 であると説明しており，これは藤井 ${ }^{14)}$ の指摘するオルタ ナティブ・ストーリーに基づくような記述である。しか し，これに続く文章では，次の第 3 章(4)節で詳しく示す が，人口減少を受けて，経済成長のための国際競争力強 化を主張しており，それは逆にドミナント・ストーリー に基づくような内容と言える.

経済活力に関連する内容についての記述は，日本文教 出版の教科書にも見られる.『統計とグラフを使いこなそ う』（p.203）と題する見開きの特集ページがあり，その 中で『国は，原則的に，労働人口が多く，子どもや高齢 者を養う負担が少ないほど，収入が多く，支出が少なく なり，経済は急激に発展します。つまり，そういう状態 が長く続く国が経済成長が長く続く国だといえます.』と 説明し，続けて『もっとも，経済は人口だけでは判断で きず，知的資源や資本，政治の問題もあります。 また， 高齢化が進んだとしても，経済の規模が大きくなってい れば，その蓄積を生かして，しばらく経済成長は続くこ とが考えられます.』と解説している.この記述の, 前半 部分は特に少子高齢化で経済発展が鈍化していくことを 「原則的」であるとしており, 後半の最後, 『その蓄積を 生かして，しばらく経済成長は続くことが考えられます』 といら記述からは，少子高齢化していく社会では将来的 には，成長が続かなくなるという印象を与える内容であ ると考えられる.

\section{（4）「外に打って出るしかない論」に関する教科書内容 についての考察}

外に打って出るしかない論の前提には，世の中にはグ ローバル化の潮流があるという認識があると考えられる が，これもまた前項での少子高齢化と同様に，学習指導 要領において，公民的分野学習の導入として現代日本の 特色として理解させ，社会への影響を気付かせることと
規定されている.

そうした学習指導要領に基づきすべての教科書の導入 部分では，現代は人や物，お金など，各国が結びついた グローバル化した世界である，といった説明に加えて， いずれの教科書も, グローバル化の肯定的な側面に加え, 否定的な側面についても言及している（表-2）。しかしそ こでは，グローバル化の進展そのものに対して疑義を呈 するというよりは，グローバル化の進展を前提として， いかに適応していくかという論調であることが見受けら れる．例えば，『グローバル化の進展によって，「地球上の すべての人々の幸福なくして自分の幸福は望めない」とい うことが，い上いよ明白な事実となってきています』（東京書 籍, p.149), 『今後も, 社会のグローバル化が進んでいく なかで』(教育出版，p.13）といった，グローバル化を必 然のものと捉えるような表現や,『国家の壁をのりこえた 地域機構は，EUのほかにはまだみることができません』 （帝国書院. p.182），『日本経済にとって，貿易や投資を 自由化し，人の移動や技術協力を促進することが課題に なっていて』（清水書院，p.120）など，経済の自由化・ グローバル化を推進すべきものと捉えるような表現が見 られる。

加えて日本文教出版の教科書冒頭では，貿易額推移の グラフ（図-2）を載せ，『現代社会は国際的な社会だ。な

表-4 外に打って出るしかない論の論点の整理

\begin{tabular}{|c|c|c|c|c|c|c|c|}
\hline $\begin{array}{c}\text { 「外に打って } \\
\text { 出るしかない論」 }\end{array}$ & \begin{tabular}{|l|} 
東京 \\
書籍
\end{tabular} & \begin{tabular}{|l|} 
日本 \\
文教
\end{tabular} & \begin{tabular}{|l|} 
教育 \\
出版
\end{tabular} & \begin{tabular}{|l|} 
帝国 \\
書院
\end{tabular} & \begin{tabular}{|l}
$\begin{array}{l}\text { 育鵬 } \\
\text { 社 }\end{array}$ \\
\end{tabular} & \begin{tabular}{|l|} 
清水 \\
書院 \\
\end{tabular} & \begin{tabular}{|l|} 
自由 \\
社
\end{tabular} \\
\hline 交流·物流の活性化 & P.8 & P.12 & P.172 & P.10 & P.24 & P.16 & P.4 \\
\hline 生産の効率化 & P.9 & P.188 & P.12 & P.140 & P. 34 & P.121 & P.122 \\
\hline 経済の発展 & & & P.6 & P.2 & P.24 & P.17 & \\
\hline 途上国の雇用拡大 & & & 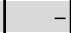 & P.10 & & P.17 & \\
\hline 肯定的 ブロック経済の反省 & P.145 & P.189 & P.174 & - & & P.121 & P.122 \\
\hline 食料の海外依存 & P.9 & P.202 & P.172 & P.144 & P.24 & P.146 & P.180 \\
\hline エネルギーの海外依存 & P.166 & P.201 & - & & & P.169 & \\
\hline 貿易の & P.9 & P.3 & P.13 & & & & \\
\hline 地域綪 & P.155 & P.189 & P.199 & P.182 & P. 163 & P.121 & \\
\hline 経済危機の伝播 & P.140 & P.189 & P.6 & & P.24 & P.17 & P.4 \\
\hline 的産業 & & & P.172 & P.140 & & P.120 & - \\
\hline 格差 & P.9 & & P.172 & P. 10 & P.24 & P.17 & \\
\hline 海外 & & 20 & & & & & \\
\hline
\end{tabular}

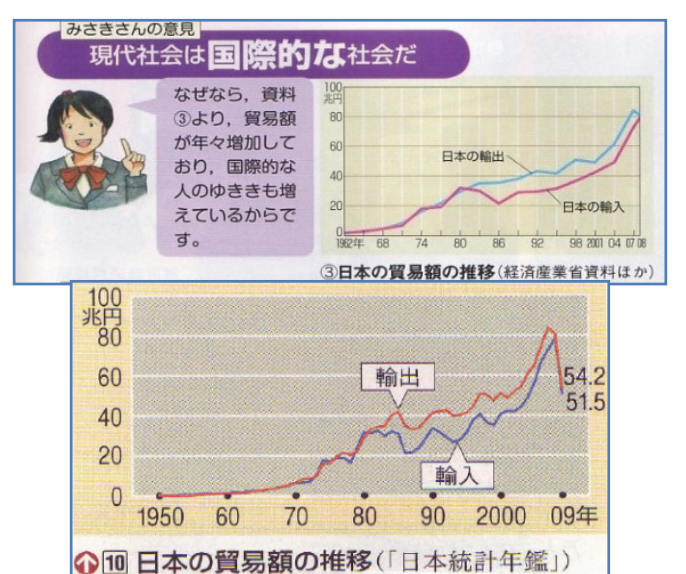

図-2 貿易額推移についてのグラフ（上 : 日本文教出版(p.3), 下: 東京書籍(p.9)) 
ぜなら，貿易額が年々増加しており，国際的な人のゆき きも増えているからです.』(p.3) という意見を載せてい る.しかし，とりわけ経済のグローバル化を考えるにあ たっては, 2008 年に発生した世界金融危機は非常に重要 な意味を持つと考えられるが，ここでのグラフは 2008 年までのデータしかなく, 2009 年の貿易の急激な落ち込 みが含まれていない. なお, 東京書籍, 帝国書院の教科 書にも同様の貿易推移を示寸グラフは掲載されているが, いずれも 2009 年までのデータとなっている (図-2).

こうした限定的なデータを基にした主張を載せること は，「事実を正確にとらえ，公正に判断するとともに適切 に表現する能力と態度を育てる」と目標を定める学習指 導要領に照らし合わせても，適切とは言い難いのではな いかと考えられる。

さらに言えば，上述の各教科書の貿易の推移はいずれ も「額」であるが，日本の経済規模もまた，名目 GDP 值で 1950 年代から現在まで, 数十倍に拡大してきた中で 単に貿易額の増加だけを見て，現代を国際的な社会とす るのは適正さを欠くものであると考えられる，そもそも グローバル化の程度を考えるに当たっては, 貿易の名目 額よりも，国の経済が貿易にどの程度依存しているのか によって, 国内経済と貿易との適切なバランスを検討し ていくことも重要となろう.

しかし，そうした記述が見られるのは，日本文教出版 のみである. その日本文教出版は貿易依存度のクイズに 対する解説として, 国別貿易依存度のグラフ（図-3）を 載せ, 図中の国の中で, 『日本はアメリカに次いで輸入依 存度が低い国です，答えをまちがえた人は，日本は食料や 資源の輸入依存度が高いといら知識から, 解答を考えたの ではないでしょうか.』(p.202) と説明している.

ここで，東京書籍の教科書を見ると，『日本，ドイツ，中 国などのような, 輸出に大きく依存し』(p.172) という，上 述の日本文教出版が指摘している間違いを犯しており, 問題のある表記と言い得るものであるが，そもそもこう した記述が見られることは，教科書の制作側に先入観が あり，事実情報を確認する，という当たり前とも言うべ き態度を欠いている可能性も考えられる.

一方で, 割合を用いた情報の中でも食料やエネルギー についての言及は多く, 食料自給率は自由社以外のす心゙ ての教科書がグラフを載せ, エネルギー自給率について も 3 社がグラフ， 1 社が本文内で，説明がある.

以上の結果を踏まえると，グローバル化という世界的 潮流が存在していると説明に加え，上記のように，貿易 総額で見れば決して海外一の依存度は高いものではない が，それについての言及はほとんどなされず，食料やエ ネルギーについてのみ，依存度の高さを強調するような 内容であれば，グローバル化・自由貿易が避けられない ものであるとの認識を, 過度に受け入かねない可能性が

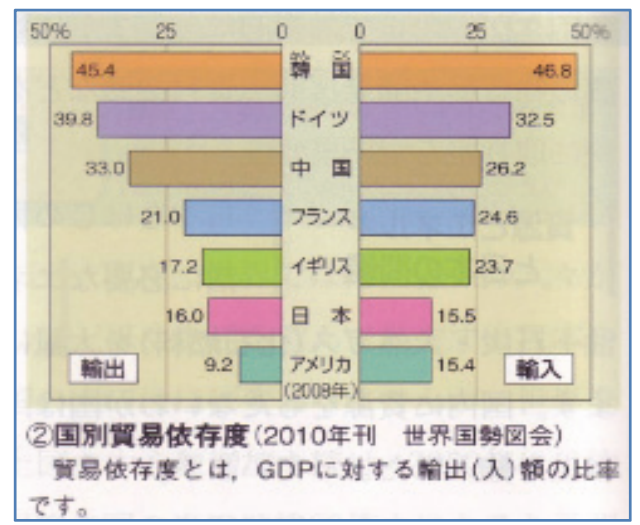

図-3国別の貿易依存度グラフ（日本文教出版(p.202)）

表-5 地方分権化の時代だ論に関する論点の整理

\begin{tabular}{|c|c|c|c|c|c|c|c|}
\hline 「地方分権の時代だ論」 & \begin{tabular}{|l} 
東京 \\
書籍 \\
\end{tabular} & \begin{tabular}{|l} 
日本 \\
文教
\end{tabular} & $\begin{array}{l}\text { 教育 } \\
\text { 出版 }\end{array}$ & \begin{tabular}{|l|} 
帝国 \\
書院 \\
\end{tabular} & \begin{tabular}{|l|}
$\begin{array}{l}\text { 育鵬 } \\
\text { 社 }\end{array}$ \\
\end{tabular} & \begin{tabular}{|l|} 
清水 \\
書院 \\
\end{tabular} & \begin{tabular}{|l} 
自由 \\
社
\end{tabular} \\
\hline 肯定的中央 & P.93 & P.95 & 5.105 & & & P.74 & \\
\hline 財·権 & P.93 & P.96 & |P.114 & $\begin{array}{l}4 \\
4\end{array}$ & P.100 & P.133 & P.105 \\
\hline 丕定的国の & & P.92 & & & 100 & & \\
\hline
\end{tabular}

\section{考えられる.}

実際に，そうしたドミナント・ストーリーの「経済成 長のためには外に打って出るしかない」とする記述が見 られるのが, 育鵬社の教科書である.『日本経済のあゆみ』 という項では, 『日本経済は, 加速する少子高齢化の下で どう国際競争力を高めるか（中略）と言う問題に直面し ています.』(p.149) と記述している. また，第 3 章(3) 節で示したように人口減少を受け,『今後, 日本経済を成 長させていくには，生産費を下げる技術を開発・導入す るとともに，グローバル化する経済で強い存在感をもつ 新しい商品を次々と開発することなどが重要です.』 （p.150）と解説し，青森産のリンゴが北京市内の市場で 取引される写真や，外国人観光客の写真などを挿入して いる. このように育鵬社の教科書では, 少子高齢化する 日本経済の未来として海外市場への展開の重要性が詳し く説明されている.

\section{（5）「地方分権化の時代だ論」に関する教科書内容につ いての考察}

まず，地方分権についての各社の説明を以下に記す． 『それぞれの地方公共団体が地理的, 社会的, 経済的な 特徵に応じた独自の活動を行えるようにする』(東京書籍, p.93), 『地域の特徵に応じた政治を行うには, 国が地域 の問題にあまりかかわらず，できるだけ地域住民の判断 にゆだねるしくみが必要』(日本文教出版, p.95)，『国に 権力が集まりすぎると，国民の意思で政治を動かすこと が難しくなってきます. 民主主義の実現のためには，(中 略）地方分権が望ましいともいわれます』(教育出版, p.105), 『国と地方公共団体とが対等の関係で仕事を分担 して政治を行う地方分権へと，政治のしくみを変えてい 
くことをめざし』(帝国書院，p.66)，『国は外交や防衛な どを重点的に行い，地方にできることは可能な限り地方 に任せるという，地方分権の考え方が重視されるように なりました.』(育鵬社，p.100）、地域住民がその地域に 必要な政治をみずからおこなうために，地方公共団体の 権限を拡大寸ることが地方分権である』(清水書院, p.75)， 『現在，地方に自立性が求められ，地方自治体の権限と 責任が大きくなっています，住民も，自分たちの地方の 行政と財政に，いっそう積極的な関心をもつことが求め られます.』(自由社，p.105）と，地方分権の必要性が説 明されている

その中で，地方分権の課題として挙げられているのは 権限および財源である. 例えば, 『国からの支出に依存し ているため，使いみちについても国の意向に配慮し，地 域の独自性が出しにくいといら指摘があります』(育鵬社, p.101）といった，権限および財源の移譲を課題とする内 容が，全ての教科書において見られる.

また，育鵬社は地方政府と中央政府の役割分担につい て『経済大国に成長し，国際化の時代をむかえたことか ら，国は外交や防衛などを重点的に行い，地方にできる ことは可能な限り地方に任せるという，地方分権の考え 方が重視されるようになりました.』(p.100) と論じてい る. 5 社の教科書では, 地方分権について論じる中では, この様な国が行うべき役割については明記されていない それらでは, 『国と地方公共団体の役割分担を明確にす る』（清水書院，p.75）という記述や，『国の行う仕事と のバランスをとりながら』(教育出版, p.105), 『国と地 方公共団体とが対等の関係で仕事を分担して政治を行う 地方分権』(帝国書院，p.66）という記述もあるが，具体 的な分担内容についての記述はない.

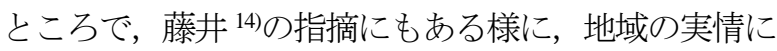
合わせた行政サービスの提供は公益を高めるものであり, その際には地方分権が重要な役割を担うことは間違いな い. しかし一方で，提供するサービスが一つの地域の範 疇を超える，交通やエネルギー，経済対策などの行政サ 一ビスについては，中央集権下での行政に利があるとも 考えられるのである.

そうした中で例えば，日本文教出版は地方の自立につ いて,『地域の自立へ向けてけんめいな努力を続けている 市町村があります。（中略）たいせつなことは, 地域の自 立や再生は, 国の政策によるものではなく, 何よりも地域住 民の意欲と土夫にかかっているといらことです.』(p.96) と 説明をしている．もちろん，そうした地域自身の創意工 夫がその地域の自立・再生にとって重要であろうことは 否定しないが，新幹線や高速道路など国家事業で整備さ れる交通インフラが地域活力の趨勢に少なからず影響を 及ぼしていることも考えられる16)。それにも関わらず， 地域の活力を国の政策ではなく，地域住民の意欲と工夫
に帰着する説明には，懸念を抱かざるを得ない．

公益の増進を図るならば，地方政府と中央政府の適正 なバランスこそが重要であると考えられるものの, 国内 における地域間の横断的な行政サービスに焦点を当てた 内容はどの教科書にも見受けられなかった。 なお，そう した地方を結ぶ交通インフラについては地理的分野にお

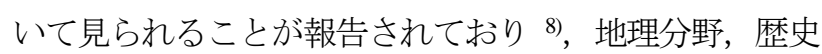
分野も含め, 社会科の教育全体を含めて, 総合的にその 内容を検証していくこともまた必要となろう.

以上より各教科書は，中央集権と地方分権それぞれの メリット・デメリットを踏まえたより善い行政のあり方 の議論を促すというよりは, 基本的には地方分権推進が 望ましいものであることを前提とした内容となっている 様子が伺える.

\section{4. まとめ}

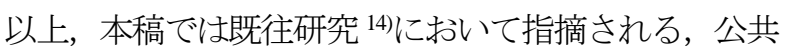
政策を巡る複数の「ドミナント・ストーリー」すなわち 広く一般の世論において共有認識されているストーリー, あるいはナラティブ (物語) を手がかりとして, 教科書 内容についての分析, 考察を行った結果, 以下の様な知 見が得られた。

第一に，公共事業そのものに対するネガティブな内容 としては, 直接的に「公共事業は無駄」という印象を与 えかねない内容が，一部の教科書（7 社中 3 社）ではあ るものの見られた，さらに，その実施主体として，政府 や行政の無駄や非効率を指摘する記述は 5 社の教科書に おいて見られた. とは言えそうしたネガティブな内容が 見られない教科書も 7 社中 2 社あった.

第二に，財政問題についてすべての教科書で共通する のは，日本財政の危機を懸念する内容であった，一方で 国債についての説明は十分とは言えず, 中には,「一人当 たりの借金」や「一日当たりの国債費」という, センセ ーショナルにその深刻さを強調する内容もあり，必ずし も正確・公正な説明がなされているとは言い難い状況で ある可能性が示唆された.

第三に，「右肩下がり宿命論」および，「外に打って出 るしかない論」については, 想定したドミナント・スト ーリーのように, 日本経済停滞の要因としての説明や海 外展開の必要性を指摘する内容は, 日本文教出版および 育鵬社の教科書には一部見られるものの, 他の教科書に は見受けられない，とはいえ，その前提となる少子高齢 化及びグローバル化については，学習指導要領にも明記 されており，すべての教科書において現代社会における 特色として大きく取り上げられている.

第四に, 「地方分権化の時代だ論」については, 地方分 
権の課題についての記述も少なく, 各教科書が地方分権 推進寄りの論調である可能性が示唆された. そもそも, 学習指導要領において, 「地方自治の基本的な考え方につ いて理解させる．その際，地方公共団体の政治の仕組み について理解させるとともに，住民の権利や義務に関連 させて，地方自治の発展に寄与しようとする住民として の自治意識の基礎を育てる.」とあるように, 国の方針と して地方自治の重要性を強調するものとなっている.

以上の様な結果を踏まえると, 公共事業に対しては必 ずしも，直接的にネガティブな記述がなされているわけ ではないが，間接的に公共事業に対してネガティブな印 象を付与する可能性を秘めたナラティブ/ストーリーに 沿った記述が様々な形でなされている，という様子を見 て取ることができた．特に財政に対する問題意識を促す ものが挙げられ，巨額の国債残高の図示や，少子高齢化 の中での社会保障費の増大が強調されている. また, 田

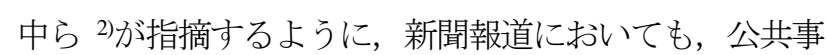
業は財政問題として頻繁に批判的な報道がなされている. そのように公共事業の問題，さらには現代社会の問題と して, 財政が挙げられるにもかかわらず，「一人当たり国 債費」や「一日当たり国債支払い,「「国家財政は一家の 家計と同じように」といった内容に代表されるように, 財政についての知識教育が，本研究で対象とした教科書 においては十分にはなされているとは言い難い状況が示 唆された.

こうした財政問題を巡る教育状況に加え，社会資本整 備の重要性・必要性を軽視させか子小ない少子高齢化やグ ローバル化, 地方分権化が現代社会の特色として強調さ れている教育の現状も踏まえると, 財政が危機的状況の なかで，公共事業の必要性は低いから削減してもよい」 という主張が，十分に検証されることなく，人々に容易 に受け入れられてしまう可能性が危惧されるものと考え られる。

ついては, 今後は他の分野や他の学年の教科書, 実際 の現場での教育内容などを検証するとともに，それらの 内容を適正なものへ是正していく必要性があるものと考 えられる，ただし，実際の教育の現場において教科書は 一つの教材にすぎず，また公民以外の様々な教科もある こと, 加えて教員の授業の仕方等によって実際の教育内 容や，それにより児童・生徒もつ認識は大きく変わりう る. そのため, 教育の現状を明らかにするには他の教科 や学年など，複数の教材に範囲を広げた検証や，教員側 の認識の検証もまた必要であろう。そして, 特に教育に 必要とされるのは現場の教員自身の, データ等に基づい た客観的かつ正確な視点であり，ただ教科書通り一面的 に教えるだけではない常に探究する姿勢であるのではな いかと考えられる。
付録

付録-1 公共事業不要論に関連する記述内容 p.80 政治の役割を, 国の安全保障や治安の維持などの最小限のも のにとどめようという考え方(「小さな政府」)がありました.これに対し て, 現代では, 政治は人々の生活を安定させるため, 社会保障や教 育, 雇用の確保など, さまざまな仕事を行うべきだと考えられています (「大きな政府」).

(前略) 行政が重要な役割を果たすことがめずらしくありません.た だ, 政治の役割が過度に大きなものになると, 企業などに任せられる 仕事まで国や地方公共団体が行ってしまうことがあります. また, 国や 地方公共団体は企業のように倒産することがありませんから, 仕事が 非効率なものになりがちといら問題もあります。

p.81 公務員の仕事には, 国や地方公共団体全体よりもそれぞれの 部門の利益を重視寸る傾向や, 機械的・形式的に行政を行う官僚主 義におちいりやすいなどの弊害がしばしば見られます.さらに日本の 場合, 公務員が退職後, 在職中の仕事に関連する企業なじに再就職 する「天下り」の問題も指摘されています.このため日本では, 簡素で 効率的な行政をめざす行政改革が進められてきました.

【コラム】たてわり行政の見直し〜「幼保一元化」の動き〜

p.132 市場では供給されにくい公共施設(社会資本)をつくったり, 医 療や教育などの公共サービスを提供したり，あるいは社会保障のた めの支出を行ったりして, 国民のくらしをよくするのは政府の重要な役 割です。

景気を調節することも政府の役割です（中略)経済はできるだけな だらかに拡大していったほうが望ましいので, 不景気のときには, 政 府は減税を行ったり公共事業への支出(公共投資)を増やしたりして, 生産や消費の活動を活発にしようとします. (中略)好景気のときに は, 政府は増税や公共事業の削減によって景気をおさえようとしま す.このように, 財政の活動を通じて景気の波を調節する政策のこと を財政政策といいます。

p.104 内閣が責任をもつ国の行政活動は, 安全保障, 治安の維持, 経済・産業の振興, 道路・河川整備などの公共事業, 医療や年金の社 会保障, 教育・文化の向上, 公害規制や生活環境の保全などさまざま 私たち国民の生活全体に密接に関連しています。 このように行政活動が国民生活の広い範囲をカバーするにつれて, さまざまな弊害も生じています. まず, 行政活動が複雑になりすぎて, 国会が行政を適切に監督したり，国民が行政の動きを理解したり寸る ことが難しくなってきました. そこで行政に関する情報公開がたいせ つになっています. また, 行政組織の財政や人員の規模が大きくなり すぎ(大きな政府)，むだが多く非効率になります. そこで, 行政の任 務を減らして小さな政府をめざす行政改革がす寸められています。 具体的には, 政府関倸の組織を民営化し, 経済活動に対寸る規制緩 和を行い, 公務員の数を減らし, 地方分権の推進など行政組織の効 率を高める試みがなされています. (中略)複雑で大量の行政の仕事 をす寸めるためには, 実際に法律案や予算案をつくり, 実施する多く の公務員 (政府職員)が必要です. 公務員は, 行政に必要な専門的 知識や技術をもっています.しかし，公務員は，自分の所属する行政 組織のせまい利益を優先しがちです(たてわり行政)。

p.106【図】予算の仕分け作業:2009年, 政権交代にともない, 前政権 の予算からむだをなくすために初めて行われました. 議論は公開さ れ, 合計約1.6兆円の事業が不要と判断されました.

p.107【コラム】大きな政府と小さな政府:大きな政府は公正を，小さな 政府は効率を強調した考え方だといえます. どちらも国の運営に必要 な考え方なので, いっぽうにかたよらないバランスが必要です. 近年 の日本は, 規制緩和, 国営・公営事業の民営化, 地方分権の推進な ど, 国のはたらきを小さくする政策も多くみられました.

p.139【図】独占禁止法違反を報じる新聞

p.160 経済にかかわる政府の仕事は, 大きく四つに分けられます.

(中略) 第二に, 道路や住宅·上下水道, 学校·図書館・博物館·病院· 公園などの社会資本を建設し, 警察・消防, 教育・科学振興, 社会保 障などの公共サービスの提供も政府の仕事です.

【写真】新幹線の整備(2011年, 青森市)

p.166 多くの人々が社会的に共同で利用する施設を，社会資本とい います. 社会資本の整備は, 個人や企業努力だけでは達成しにくい ために, これまでは国や地方公共団体が公共事業として整備してきま した. 社会資本には, 高速道路, 港湾や工業用水など, 産業活動の 基盤となるものがあります. また, 上下水道, 街路や公園や緑地, 学 
校・図書館・体育館, 病院や老人ホームなど, 衛生, 環境, 教育・文 化, 社会福祉などの生活基盤となる施設もあります. 現在, 産業基盤 は充実し, 生活基盤の施設もかなり整ってきました. これらの設備をじ ようずに活用していくためには, コミュニティやボランティア, NPO組織 など, 地域社会の支援組織が欠かせません. 今後, 社会資本の整備 には, 既存設備の活用を含めて, 人々の生活の質を向上させることを 重要な目標にして, 地域社会の支援組織と協力寸ることが不可欠で す.

【図】公共事業の見直しを報じる新聞: 公共事業のあり方や要不要を めぐって, 費用と効果の面で議論がさかんです。

【図】社会資本の整備とこれからのNPOの役割:これまで, 政府でまと めて対応しや寸かった. これから, 多くの人の同意が必要で, 画一的 になりがちな政府のやり方では対応しづらい.

p.175 安定した経済成長を実現するために, 政府は税制政策を，日 本銀行は金融政策とよばれる手段をとり，ゆきすぎた経済のうごきを おさえる役目を果たそうとします. 寸なわち, 政府は, 不況時にはたと え財政赤字を出してでも, 公共事業を盛んにしたり, 減税を行ったり, 雇用保険の給付を増加させたりします. (中略)反対に, インフレーシ ヨンの危険があるときには，政府は，公共事業をひかえたり減税したり して, 景気の過熱をおさえようとします。

p.90 かつての行政の仕事は, 治安の維持や外交・防衛などが中心 でした. しかし，日本の社会が大きく変化するなかで, 行政の仕事は 急激に拡大してきました. なかでも, 教育や福祉, 医療, 環境保全な 行政の重要な課題となっていま寸, そのため, 行政のし くみが複雑になり, 公務員の数や行政にかかる費用も増えたことで, 行政権の力が大きくなっていきました(行政権の肥大化). 同時に, 税 金が高くなるなど, 国民の負担も大きくなりました. 政府が大きくなりす ぎると，国民が政府を動かすことが難しくなり，民主政治がはたらきに くくなる面もあります. そこで, 大きくなった行政の仕事を整理·縮小し て, より「小さな政府」を実現しようとするさまざまな行政改革が，日本 でも1980年代ごろから行われてきました. 国の仕事とされてきたことの うち，民間に任せられるものは民間に移そうといら, 公的な事業の民 営化や,さまざまな規制緩和が進められてきました。

p.91【コラム】行政をになう公務員:各省庁で行政を担う公務員は, 「全体の奉仕者」として, 専門性の高、知識と技術を生かしながら, 国 民の生活を向上させるために働いています. しかし，一部の公務員に よる, 政策の立案を通して政治を動かす「官僚政治」や, それぞれの 省庁の利益を優先させる「たてわり行政」など,ささざまな問題が指摘 されてきました.こうしたなか, 2004年以降, 社会保険庁によるずさん な年金業務の実態が明らかになったことや, 公務員の「天下り」(再就 職)の実態と, 特殊法人に対寸る省庁からの不透明な補助金の問題 などが報道されました. 必要に応じた組織の見直しや再編が, 常に求 められています。

p.153【図】政府の財政政策のしくみ:好況のとき, 増税や, 公共事業 などの歳出を減らすことで行き過ぎた景気を抑える. 不況のとき, 減 税や, 公共事業なじの歳出を増やすことで, 影気を上向きにする。 p.146 政府は, 道路・ダム・港などの社会資本をはじめ, 警察・消防・ 教育・国防といった公共サービスを提供します. (中略)こうした性質 の財やサービスは, 民間企業が市場を通して提供するのは難しいの で, 原則的に政府が, 納められた税金をもとに提供しているのです. p.164 わたしたちの生活や産業を支える基盤となり,だれもが共同で 利用できる公共施設のことを社会資本, サービスのことを公共サービ スといいます.これらは，民間の企業によって利益を得る目的で供給 されるのではなく, 国や地方公共団体による公共事業として, わたし たちの生活を向上させるために, 公平に供給される必要があります. 戦後の日本では, 大規模な工業用地や港湾をはじめ, 産業に関連す る社会資本が優先的に整備されてきました. その結果, 工業生産を中 心経済が大きく成長した一方で, 生活に関連する社会資本の整備は 後まわしにされてきた面があります.今後は, 福祉施設や病院などの 社会資本を含めた, 生活環境全体の整備と充実が必要です。

\section{【図】社会資本の整備に使われる予算の推移}

p.165【図】主な国の社会資本と公共サービスの整備率(下水道普及 率, 道路舗装率, 一人当たり公園面積, 人口10万人当たり図書館数） 国の行政は，国民の生活に直結寸る教育・文化や社会保障，公 共事業, 産業振興, 治安などの政策を効率的に, また専門的に行うた の行政は, 仕事量が増え, 内容も専門化し, 組織も拡大しました. 国 の事務が, 複数の大臣や省・庁によって分担されているため, 政策に 統一性がなくなり,なわばり争いが生まれているといら声もあります。
国民自身の努力で行うことのできる部分にまで行政がはいりこんでい るのではないか, 官僚による行政指導が強すぎるために, 地方の行 政や企業なじの活力を弱めているのではないかといら意見も出てきま した. 一つの政権が長期間続いたために, 行政と特定の議院や政党 が密着してしまったといら批判もあります。

p.156 私たちの生活を見わたすと, 政府によって提供されているモ) やサービス(公共サービス)もたくさんあります.たいていの道路や橋 の建設といった公共事業, 外交, 防衛などは民間企業によっては提 供されません。

p.158 国の1年間の支出を歳出といいます. 道路工事や下水道の整 備, 災害に備えた山や河川の工事(治山・治水工事), 防衛などに対 する支出のほか, 年金や医療保険などを維持するために, 保険料収 入の不足を補っています。

p.162 私たちの生活は, 道路や下水道, 公園, 文化会館などの社会 資本によって支えられています。こうした社会資本の整備は公共事業 とよばれ，国や地方公共団体の歳出，そして財政投融資計画のお金 でまかなわれています。高度経済成長期には, 道路が社会資本整備 の約4割をしめていました. しかし，現在ではその比率は低下し，下水 道環境衛生などに比率が高くなっています。

【図】拡大寸る羽田空港(写真) : 小らいは2点で,一つ目は, (中略) 国 内の航空路を拡大し，それにともなう地方空港の活性化をめざすとい うものです.二つ目は, 国際線の増便によって, (中略)海外空港との 競争に勝つことをめざすというものです.

\section{[図)社会資本整備の割合(1970年度と2008年度)}

p.163 時代の変化とともに, 求められる社会資本整備と公共事業は変 化していきます.これからは, 持続可能な社会を築くために, 地球温 暖化対策などの環境対策にも力を注ぐことが重要です. また, 広い地 域を結び航空路の拠点となる機能をもつ国際空港や港湾の整備な ぞ, グローバル化のなかで日本の国際競争力を維持するための公共 投資など, 21世紀にふさわしい公共事業を行う必要があります. 社会 資本は, 税金などの国民のお金を使って整備寸るのですから, どの ような社会資本が必要なのか, 私たちもよく考える必要があります。 【コラム】公共事業について:Yes道路や公園が増えるのだから, 生活 が便利になる. 公共事業は, 働く場を提供する. No:少子高齢化の現 在, 公共事業はなるべく減らして, その分社会保障を充実させるべき だ. 無䭾な公共事業に使うお金があるなら，その分減税すべきだ.

p.90 政治の重要な決定を行政機関が行うようになってきました.この 行政権の肥大した国家を行政国家しいいます.行政国家では, 自由な経済活動などが規制されてしまうといった批判も行われるよう になり，国営·公営事業の民営化をはかったり，国の権限でおこなっ ていた仕事を地方にまかせたり, 行政機関の許認可権を見直し, 規 制緩和をはかるなどの行政改革が行われています。

【コラム】さまざまな行政改革:例えば, 国が鉄道を運営していると, な ぜ無駄がでてしまうのか考えてみましょう

p.117【コラム】公企業の民営化: 公企業の経営は, 市場競争が制約 され, 経営不振や倒産への危機感がうすいため, 非効率的になること があります，そこで，公企業を私企業とすること(民営化)により，その 経営の効率化がはかられます. 民営化によって料金や価格が安くな る場合もあれば, 利潤の得るために, 料金や価格が高くなることもある ので, 民営化をす寸めるには注意が必要です。

p.136 注勫:例えば, 道路や公園, 公衆衛生や上下水道, 警察や消 防など, 人々が共同で使用できる財やサービスは, 一人ひとりの個人 が希望して購入できるものではなく, 一人ひとりから料金を徵収するこ とも困難です.このような財やサービスは私企業によっては供給され ません。

【写真】暮らしの中にある社会資本(道路, 学校, 病院, 公園) : 日本で は, 産業道路や港湾·空港の整備なら゙, 産業基盤のための社会資本 の整備はかなり行われてきました. より高度な産業基盤のために, 今 後は科学技術の研究・開発や, 教育の充実が必要です。

p.138 利用者のほとんどいない厚生施設などの無䭾な社会資本を建 設するようなことは, さけなければなりませんし, 公債の発行は慎重に 行う必要があります。

p.139 道路や河川の整備など, 国の直轄事業の費用負担や, 府の巨 額プロジェク外負債, そして1970年代の府政により, 社会保障費とそ れにともなう人件費の増大など, 大きな負債を抱えていたため, 公債 を発行し続けてきました。 そこで, 大阪府は職員給与を都道府県最低 水準まで引き下げ, 建設事業費を大幅に削減しました. また市町村補 助金の削減なども行い, 歳出を抑えることにより財政を再建しました。 多くの地方公共団体にとって, 限られた予算の中で最大限の効果を 
あげるために, いかに無䭾な支出をおさえるかが, 財政改革の出発 点といえるでしょう。

p.140 不況のときには, 企業の生産活動が振るわず，消費も低迷し て, 物価が下落し続けるデフレーションの状態になるおそれがありま す.このような場合, 景気を刺激する財政政策がとられます. 公共事 業への支出(公共投資)を増やしたり，減税を実施して需要をつくり出 したりします。

【写真】ジョン・メイナード•ケインズ: 不況の時には, 政府が公共事業 などの積極的な財政政策をとるべきとする経済理論を唱えました.

【図】財政政策と金融政策

p.187【レポート課題例】ムダのない行政の国, 日本:必要な公共事 業と，そうでないものをきちんと仕分けし，公共事業費を削減します。 そして, 行政と公務員の仕事を見直し, 税金の無駄づかいをなくしま す. p.65 行政権の拡大がす寸むと, 政治上の重大な決定が事実上, 行 政機関にゆだねられてしまいかねない（中略)行政費用のもたらす 財政赤字もふくらみ, 国民の負担も大きくなっている. p.74【写真】市街地を走る路面電車: (前略) 路面電車など公共交通 を充実させ，自動車の使用を減らすことで，高齢化や温暖化への対 策をはかっている.

p.126 財政のはたらきの第一は, 社会資本や公共サービスの提供で ある. 民間の企業では資金を出すことがむずかしい社会資本の整備 を行ったり, 警察・消防など国民の生活を守るためのしごとをしたり， (中略)財政の三つめのはたらきは, 景気の変動を調整(景気の調整) をして経済を安定させることである. 不景気のときには財政支出を増 やしたり, 減税によって経済活動を活発にする. 景気がゆきすぎてイ ンフレ傾向のときは財政支出を減らすなどして, 景気を調整するため の政策が実施される.

p.127【コラム】れからの社会と社会資本:社会資本とは, 道路・上下 水道・学校など生活や産業の基礎となる公共的な施設のことである. 高齢者や障がい者など，すべての人が利用しやすい交通手段の整 備やバリアフリー化, 地震や洪水などによる災害を未然にふせぐまち づくりなど, 地域の特性や実情を考慮しながら，人びとが安心してくら せるように, 生活者の視点に立って社会資本を充実させていくとが 求められている。

政赤字)，細分化された行政組織 てしまう(官僚支配)といった問題も生じています。

p.109 経済財は(中略)私的財と, 道路や公園のように, 社会全体て 共有し，社会のだれもが自由に利用できる公共財とに区別することが できます。

【図】政府が提供する公共財:道路, 橋, 公園

p.124 財政の第1の役割は, 公共財の生産と供給にあります. 道路, 橋, 港湾施設, 上水道, 下水道などの公共財は, だれもが自由に使 え, 基本的に国や地方公共団体が生産, 提供する経済財です。 それ らは, 国民の生活基盤であるだけでなく, 広く社会の経済活動の不可 欠の基盤となります. (中略)財政の第4の役割としては, 財政投融資 はあります. 政策上の観点からは必要でありながら，一般の金融機関 によっては十分に投資や融資が行われない事業へ，国債(財投債) などを発行して，資金を調達し，投資や融資をして，例えば，巨大な ダムの建設, 高速道路の建設, また宇宙開発, 環境保全などを行いま す.

p.138 みなさんの住む地域には, 古くからある道路や橋, 溜め池や 用水，堤防などがありますか. そのそばにその完成を祝ったり，建設 を指導したりした人を讃えた石碑がありませんか. 昔から人々は, 生 活と生産のために必要な大規模な工事を, 地域の共同体で協力して 行ってきました. そうしてつくられ，社会が共同で利用する施設・設 備・財産を総合して社会資本(インフラストラクチャー)といいます.今 日の社会資本には，上下水道，ごみ処理場のように国民の日々の生 活に欠かせないもの, さらには道路, 鉄道, 空港, 電気の供給, 電話 やインターネットなどの通信の施設・設備など, 国民生活にも生産活 動にも共に欠かせないものがあります. また, 学校, 図書館, 博物館, 公園, 運動場などのように多くの人が使う教育・文化施設も社会資本 です。そのほか. 自然環境保護の観点から行う自然環境の補修·整備 や, 遺跡, 寺院などの文化財·文化遺産の保護·整備なども, 過去か ら未来一と持続していく社会のための社会資本の整備として考えられ ます. 社会資本の建設と維持には巨額の費用がかかるため, 多くの 場合, 通常の収益事業として行うことができません. なかには, 電気・
ガス・水道や公共交通機関などのように, 使用料金を徵収して施設・ 設備の建設費や運用の費用をまかなう場合もありますが, 多くのもの は, 国や地方公共団体によって税金や公債からなる公的資金を投入 して整備されます. 特に道路, 港湾施設, ダムなど長期にわたって巨 額の費用がかかる建設事業は公共事業と呼ばれ，公的資金を主な財 源しして, 長期にわたって投資したり融資したりしてまかなわれます。 快適な生活といら意味から，最近では，社会資本の質も問われるよう になりました. 公共交通機関や公共の施設·設備は, 高齢者や障害の ある人たちも利用しや寸いように, 段差をなくしたり，点字の併記を設 けるなどのバリアフリー化が進んでいます。

【図】社会資本の種類

【図】公共投資の分野別配分の推移:道路予算の割合は減り，住宅都 市環境予算への割合が増えている。

【図】公共投資予算の推移(1980年〜2009年) : 最近の予算額は1980 年代の水準に落ちてきている.

付録-2 日本財政破綻論に関連する記述内容 枝教育や道路整借なじ特定の費用の一部については国から 国庫支出金が支払われます. 地方公共団体の借金である地方債の 登行残高む高い水淮にあります，最近では，財政難に苦しむ地方公 少なくしたり，事業をけずったりして, 財政の立て直しに向けて努力し ています。

【図】地方債の発行残高の推移(1980年〜2008年)

p.131 公債は借金ですから，政府は公債を買った人に利子を支払 い, 元金を返済しなければなりません. 安易に公債を発行すると利子 の支払いや元金の返済が大変ですし，将来世代に負担を回すことに もなるので, 公債の発行は慎重に行わなければなりません。

【図】国債の歳入に占める割合と国債残高(1970年～2010年)

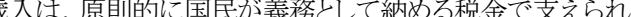
税金で不十分な場合は, 法律に基づいて発行される国債(国の借金) 補正するための地方交付税交付金，全国の公共事業関係費，文教・ 科学振興費, 防衛関係費等がその使いみちです.また, 地方公共団 体の財政支出は，土木費や教育費など，それぞれの地域住民のくら しに密着した事業にあてられます。

【図】国の収入と支出(1995年度と2010年度)

p.163 国が公共事業に必要なお金を国債でまかなうのは, 家計が住 宅の建設費用を住宅ローンとして借り入れることに似ています.また, 不景気で税収が減るとやむをえず国債を発行しなければならないこ ともあります。

しかし，国債は国の借金ですから，国は，発行した国債には利子を支 払い, 期限がきた国債に対しては元金も返済しなければなりません. 国債の利子の支払いや元金の返済は, 将来, 最終的に国民の税金 でまかなわれます。白ため, 国債は, 発行が必要な場合でも慎重 に発行額を検討しなければなりません。

【図】国債依存度と国債残高の推移 (1970年度〜2010年度): 日本の 人口を 1 億 2500 万人しして, 2010年の国債残高から, 国民一人あたり 約何万円の借金になるか, 計算してみましょう.

【図】財政投融資が投入された伊勢湾岸道路:財政投融資とは, 社会 資本の整備や公共サービスの充実を目的に, 政府が特別な債権で 集めた資金を, 政府に関係する組織や地方公共団体一投資や融資 をすることです。

【コラム】国債増加の問題点:(1)将来の世代に負担が先送りされる. (2) 日本経済一の国際的な信用がなくなる. (3)一般歳出が減るので, 政 府の自由にできるお金が少なくなる(財政の硬直化)。

p.151 1年間の予算は, 税収の額をもとに立てるのが原則ですが, 国 合, 政府公倩を登行して国民加借金を人，歲入の不足分を補いま 景気対策にも使われます,ところが，社会保障費などの歳出増加や， 度重なる景気対策などのため, 深刻な財政赤字が続き, 公債の発行 残高が年々増加しています. 政府は, 巨額の借金を減らすため, 財 政構造改革を行い, 行政経費の節約や公営企業の民営化など, 歳出 の削減を進めてきました. 公債の発行は, その返済の負担の後の世 代の人々に負わせることにもなるので, 慎重に行われる必要がありま 
【図】国債残高と国債依存度の推移(1965年度〜2011年度)

【図】一日当たりに支払われる国債費:1日当たり約 590 億円, 1 時間当 たり約25億円, 1 分当たり約 4100 万円, 1 秒当たり約 68 万円

【コラム】財政投融資：一般会計とは別に, 財政投融資といら制度があ ります. 財政投融資は, 政府が財政を通じて投資や融資を行うもの で, 住宅の整備, 道路などの都市整備, 中小企業の振興などの目的 で, 利子をとって資金を融資しています。 p.75【コラム】報道から事実と意見を区別する:とても素直に喜べな い. 新年度予算の成立にめどはついたが, 財政の先行きがますます 行額は税収を上回り44兆円にのぼる. 借金中毒の上うな財政の资がこ こにある. (2010年3月3日 朝日新聞, 社説)

p.159 歳出をまかなうのに, 税収では十分でないときには, 国の借金 である国債が発行されています。しかし，国債は期限がくれば返済 し，利子も支払わなければなりません．こうした国債費が増えると国の 財政を圧迫してしまいます。

p.164 日本の財政がかかえる大きな問題は, 税収が歳出をまかなう のに十分でないため, 財政赤字が拡大していることです. それを補う ために国債を発行しなければなりません. 国債が増えると, 利子の支 払いなど国債費が増大して財政を圧迫することになり, 歳出全体でど のような支出をするのかを, 決める余地が少なくなってしまします。

【図】国債残高と国債依存度(1965年度～2010年度)

【コラム】国債発行について:Yes国民の要望にこたえ，いろいろな政 策を実施するためには, 国債を発行すべきだ. 日本の国債の多くは 日本国民が購入するものだから問題はない. No発行しすぎると利子 の支払いなどが増え，本来行うべき政策ができなくなる. 借金を残す ことになるので, 将来世代に負担をかけ忛ることになる。 等 きなら゙、税全だけでは財政支出をまかなえないときがありま寸ってのよ うな場合, 国や地方公共団体は, 収入の不足を補うために公債を発 行し，個人や銀行に買ってもらうことで民間からお金を借り入れます。 (中略)国債や地方債の発行で公共サービスの恩恵の多くを受け取 れるのは, 現在生活している私たちです.しかし, 国債や地方債の利 子の支払いや元金の返済は, 将来, 最終的には国民や地域住民の 税金でまかなわれます. 国債や地方債の残高は年々増加しており， 果たして返済できるのかといら懸念もあります.したがって, 利用者の ほとんどいない厚生施設などの無駄な社会資本を建設するようなこと は,さけなければなりませんし, 公債の発行は慎重に行う必要があり ます。

【図】国債発行残高の推移:建設国債…公共事業などを行うために発 行, 特例国債…税収不足を補うために発行. 国債残高の増加は, 将 来世代に大きな負担を残すことになります。

【図】債務残高の国際比較(対GDP比, 1991年～2011年)

【コラム】財政投融資: 財政投融資とは, 担当する各機関や政府が債 権を発行して必要な資金を市場から調達し, 公団や地方公共団体な どに貸し出して, 社会資本整備や公共サービスの充実を図ったりする ことを言います。

p.139 財政を短期間で立て直した自治体もあります（中略）大阪 府はそれまで，企業が納める法人税の落ちこみにより歳入が悪化 し，歳出面では人件費の増大が負担になっていました．また，道 路や河川の整備など，国の直轄事業の費用負担や，府の巨額プロ ジェクトの負債, そして1970年代の府政により, 社会保障費とそ れにともなう人件費の増大など，大きな負債を抱えていたため， 公債を発行し続けてきました．そこで，大阪府は職員給与を都道 府県最低水準まで引き下げ，建設事業費を大幅に削減しました。 また市町村補助金の削減なども行い，歳出を抑えることにより財 政を再建しました．多くの地方公共団体にとって，限られた予算 の中で最大限の効果をあげるために，いかに無駄な支出をおさえ るかが，財政改革の出発点といえるでしょう。

【図】国と地方公共団体の財政の健全性(実質公債比率)

p.187【レポート課題例】借金の少ない国，日本:国債残高を減少さ せ, 健全な運営を行えるようにします. それにより，国家予算を重点的 に投資できるようにします。

清 p.131【コラム】国債: 財政の規模が大きくなり, 租税収入だけではま かないきれなくなると, 政府は国債を発行して民間から借金をするよう 書 になった(財政赤字). 不景気がつづき租税収入が減少し, 多額の国 院 債が発行されて, 国の財政を大きく圧迫している. 国債は将来にわた
って国民の税金で返済しなければならないものであり,その発行は慎 重にしなければならない

【注釈】財政投融資: 道路の建設や中小企業の支援, 生活環境の整備 など, 政策として必要であるが, 民間の金融機関ではむずかしい長期 資金の供給や，高速道路や空港など共同で利用寸る大規模な施設 をつくるために用いられる.

【図】国債残高と一般会計にしめる割合(1990年度～2011年度)

自 p.94【図】国の借金の総額の推移(1996年〜2010年)

由 $\mathrm{p} .95$ このような行政の肥大化は, 多くの国が共通にかかえる問題で すが, 我が国の場合, 特に財政赤字の深刻さが指摘されます. 国家 財政の基本は, 一家の家計と同じように1年間の収入と支出のバラン スがとれていなければなりません。 今日のわが国の財政は, 年間 40 兆円をこえる国債の発行による借入金に依存しており, 問題となって いる状態です。

【図】日本の国家予算の内訳

p.128 公債は将来の税金によって返還されることになり, 結局は政府 の財政は税金によってまかなわれることになります。

【図】各国の債務残高の対GDP比(1995年〜2009年)

付録-3 右肩下がり宿命論に関連する記述内容

㡷 $\quad$ p.12 日本は現在, 少子高齢社会に突入しています. (中略)

京 少子高齢化は, 社会にしめる働き手の数(労働力人口)が減少するこ とも意味します。一方で高齢者は年金を受給し，公的な医療保険や介 護保険などの給付を受けることも多くなります. そのため, 少子高齢化 が進むと, 国民一人当たりの経済的な負担が重くなるなど, 社会保障 のあり方に影響が出ることが予想されます。

【図】年齢別人口割合の推移(人口ピラミッド) (1969年と2009年)

【図】人口にしめる高齢者割合の推移と将来推計(1950年～2050年, 6 力国)

p.13 これからの日本では, 高齢化の進行に対応して, 活力ある経済 を保ちながら，みんなで長寿を喜び, 高齢者が安心してくらすことの できる社会をつくっていくことが求められています。

【図】国民の年金負担: 高齢者一人分の基礎年金を何人の現役世代 が支えるかを示しています。

p.136 少子高齢化が進むと，医療費や年金給付額は増えていくの に, 労㗢力人口が減るために, それらをまかならための保険料と税収 はむしろ減少していくからです。

【図】日本の人口構成の変化(1950年〜2050年)

【図】社会保障給付額の推移(1975年〜2008年)

p.6 日本の人口は2005年をさかいに減り始めました. 一人の女性が 一生のうちに生む子どもの数が減ってきたからです. (中略)子どもの

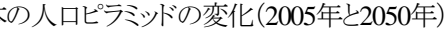

【図】年齢別人口の推移と将来推計(1950年〜2055年)

【図】昔と今の子どもの数:子どもの数は一人の女性が生涯に生む子 どもの数の平均です. 2.1 人を下回れば人口は減少するとされていま す(1950年3.65人, 2008年 1.37 人)

P.7 高齢者が増えれば, 医療や介護を受ける人の数は増えるため, 高齢者のくらしを社会全体で支える制度や仕組みも充実しなければ なりません. そのためには私たちのくらしも, 政治や経済のしくみも変 わっていかなければならないでしよう. 少子高齢化を大変な社会の問 題と考えるのではなく, そのなかでみんなが豊かにくらせる社会をど うつくっていくかを考えなければなりません．

【図】各国の高齢化率の推移(1950年～2050年, 6力国の比較)

p.170 わが国は, 子どもの少ない家族が増え，同時に高齢者も増え ているため, 急速に少子高齢社会になっています. そのような社会で は, 経済活動の担い手としても, 公的年金制度の支え手ししても, 働 きざかりの世代の役割が大きくなります.

p.203【コラム】国は, 原則的に, 労働人口が多く, 子どもや高齢者を 養う負担が少ないほど, 収入が多く, 支出が少なくなり, 経済は急激 に発展します.つまり, そういら状態が長く続く国が経済成長が長く続 く国だしいえます。(中略)もっとも, 経済は人口だけでは判断できず, 知的資源や資本, 政治の問題もあります. また, 高齢化が進んだしし ても, 経済の規模が大きくなっていれば, その蓄積を生かして, しば らく経済成長は続くことが考えられます。

【図】主な国の経済成長率(1997年～2008年) 
【図】主な国の高齢化率の推移(1950年〜2050年)

【図】日本の経済成長率(1956年〜2009年)

第一次石油危機のあった1973年ごをさかいに, 出生数は現在 まで緩やかに減少してきています.このように少子化が進んできた背 景には，どのようなことが考えられるでしょうか。 p.9 高齢化が進むなかで, 高齢者だけの世帯や, 一人暮らしの高齢 者が増え，世代間のつながりや, 地域での人と人との交流が薄れて いことが心配されています. また，高齢者の介護をだれがどのように 担っていくのかといら課題にも，わたしたちは直面しています. 政府 は, 介護に携わる人や介護システムの充実なども目ざしていますが, まだ十分な状態とはいえません. 高齢社会になると, これまで以上 に，高齢者の抱えるさまざまな課題に取り組む必要がで

【図】総人口と年齢別人口割合の変化(2005年と2030年) p.162 日本の人口は, 2004年をピークに長期的に減少し始めました。 生まれる子どもの数が, しだいに減少してきていて，一人の女性が一 生の間に産む子どもの数(合計特殊出生率)も減少しています. その 一方で, 高齢者の数は増えています. 65歳以上の人の数が人口全体 のなかでしめる割合は，すでに20\%を超えており，世界で最も高齢化 した国となっています.今後も, さらに高齢化していくことが予測され ています. 高齢社会になると, これまで以上に, 高齢者の抱えるさま ざまな課題に取り組む必要が出てきます.その一つが, 介護の問題 です.

【図】日本の総人口の推移(1950年～2055年) 平均寿命ののびと,子じもの数の減少のため, 日本は15歳以下 の年少人口が少なく, 65歳以上の老年人口の割合が高い少子高齢社 になりました，日本の場合，急速に進行したため，対策が遅れ，さま どのような影響を受けるでしようか. 例えば, 家族や地域社会のあり方 が変化したり, 労働人口が減少したり, 子どもに関連した産業をはじ めとする日本の産業全体がおとろえたりすることが予測されていま す.

\section{【図】日本の人口構造の変化(1920年～2050年)}

.20 日本は, 近年の少子化の進行と平均寿命の伸びによって, 少子 急速に変化していることがわかります（中略) 少子高齢 化が現状のまま進んでいくと, 文化的で落ち着きのある社会を築きや すくなるだろうと言われている半面, 若者文化や社会の活力を衰退さ せるのではないか, との心配もります. また, 国全体の活力への影 響も懸念されます.このほかに, 少子化による将来の労働力不足や 個人消費の伸び悩みなども日本の経済に影響をあたえることが予想 されます. また, 医療や年金の問題も重要な課題となっています.ま た，医療や年金の問題も重要な課題となっています. (中略)政府を はじめ社会全体の対応が追いついていないことから, さまざまな課題 が生じています. とくに,「育児」と「介護」が大きな問題となっていま す。

【図】日本の年齢別人口構成とその変化(2008年と2055年)

p.106 1990年代に入ると，日本の経済成長は長期にわたつて停滞す るようになりました. 今は子どもの数が減少し, 総人口に対する高齢者 の割合が高い少子高齢の時代をむかえています. 活力あふれる豊か な社会にするためには, 消費者が求めている商品を開発したり, 生産 の効率を上げるなどして, 経済を成長させることが必要です。

【図】日本の経済成長率の推移

p.150 日本は少子高齢化によって人口が減少に転じていますが, 経 済成長ができなくなるわけではありません，日本には，利用すれば高 い価值を生み出す社会資本がたくさんあり, 生産に利用できる設備 も，質・量ともに充実しています.これらをうまく使って技術革新をす寸 め, 新たな価值をもつ財やサービスを生み出すことができます。

清 $\mathrm{p} .12$ 子どもの出生数が減って少子化がす寸むいっぽうで, 総人口に 占める65歳以上の高齢者の割合が大きくなっている.このような社会 は少子高齢社会とよばれている。

構成(1930年, 2009年, 2055年)

p.13 少子高齢化の未来について心配する声もある. 高齢者のくらし を支える年金は，費用を負担する人よりも受給する人が多くなって，

現在のしくみを維持することはむずかしくなっている. 働く人が減って 産業がおとろえ, 活気のない社会になるという指摘もある.
付録-4 外に打って出るしかない論に関連する記述内容

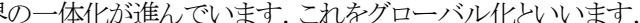

p.9 どちらがよりよい品をより安く提供できるか, 国際競争が進みま 寸. また, それぞれの国や地域が競争力のある産業力を入れ, 競争 力のないものは輸入する, 国際分業が行われるのです.

グローバル化の進展にともない, わたしたちの生活はたいいん便利 になりました. 一方, 例えば新型インフルエンザの世界的大流行のよ らに. 世界全体として各国が協力して取り組むべき課題も増えてきまし た. 世界では豊かな国々と貧しい国々の格差が広がっていることも忘 れてはなりません.このような中, 国際協力を進めるうえでの日本の役 割はいっそう大きなものになっています。

【図】外国人登録者数の変化(1980年～2009年)

【図】日本の貿易額の推移(1950年～2009年)

【図】日本の食料自給率の推移(1960年～2009年)

p.117（前略しかし，経済の自由化とグローバル化が進展した現在， 賃金や労衝時間などの格差がふたたび拡大しています. (中略)グロ 一バル化が進むにつれて, 企業間の国際競争はますます激しさを増 しています. 激しい競争にさらされた企業は, 新技術を開発し生産コ ス卜を下げる努力を行う一方で, 外国企業との提携を模索していま 寸. 事業の無駄を省き, 経営の効率化を図ることも大切です. 広大な 市場と安い労働力を求めて, アジアをはじめとする海外の国々に現 地籍の企業をつくる多国籍企業の例も少なくありません．

【図】海外に進出する日本企業数(1989年11484社と2009年21918社) p.121 グローバル化が進むにつれて, 多くの外国人労働者が日本で 働くようになり，その数は就労資格を持たない人もふくめて 100 万人近 くに上ると推定されています.一般にこれらの人たちの賃金は低く, 働く環境も劣悪で, 雇用は景気に大きく左右されます. 外国人労働者 を少子化の進む日本で不可欠な労働力とみなし, 受け入れ態勢を整 えていくのか, それともこれまでじおり限られた就労資格のもとで受け 入れを制限していくのか，日本は今，大きな選択を迫られています。

p.140 2008年の秋に起こった世界金融危機は, グローバル化する経 済がもつ負の一面をまざまざと見せつけました. (中略)このような経 済は, 一か所がおかしくなると経済全体が大混乱におちいる危険性 を内に秘めています.このような危険性が現実のものとなったのが世 界金融危機でした。

【図】世界の貿易額と国別割合の変化(1987年と2007年)

(前略) 金融の役割が大きくなった経済のことを金融資本主義と呼ぶ 人がいます.このような経済の問題点は, それが生産や雇用に負の 影響をおよぼしかねないことです。

p.141 日本の高い技術競争力も, 世界の急速な技術革新を背景に, 少しずつ低下しつつあります. 経済発展の原動力はものづくり」の技 術にあることを思い起こし，技術立国の立て直しを図らねばなりませ ん.

p.145【コラム】一国の輸入規制に他国もまた輸入規制で応じると，貿 易そのものがしだいに縮小し，ときには戦争に発展していくこともあり ます. 第二次世界大戦の原因の一つはこのような貿易紛争にあったと いわれています. 国による貿易へのこのような介入を排除し, 自由貿 易を促進して貿易の拡大を四るために, 戦後, GATTという国際協定 が結ばれました。

p.149 人, もの, お金が世界じゅうをかけめぐるグローバル化の進展 によって，「地球上の寸べての人々の幸福なくして自分の幸福は望め ない」といらことが，いよいよ明白な事実となってきています。

p.154 第二次世界大戦後, コーロッパでは, 戦争をふたたび起こさな いために, 経済関係を中心にヨーロッパの統合をめざす動きが起こり ました。

p.155 近年では, 経済の相互関係を強化するために, 自由貿易協定 (FTA)を結ぶ国も多くなっています.

p.166 日本は, エネルギー資源の約 $96 \%$ を海外からの輸入に依存し ています。

p.172 冷戦の終結後, 国際社会は急速にグローバル化が進展しまし た. 人,もの, お金, 情報なじの国境をこえた移動が活発になったの で寸，その一方で, グローバル化の影といわれる側面も目立つように なってきました. 人の移動では, 難民や不法移民の問題です. モノの 移動の代表である貿易では,「グローバルな不均衡」といわれる問題 があります.アメリカのような大量輸入・過剩消費の国と, 日本, ドイ 
ツ, 中国などのような, 輸出に大きく依存し, アメリカに巨額のお金を 貸している国との不均衡の問題です. お金の移動では, 金融資本主 義が進んでいます. 2008年にアメリカから始まった世界金融危機は, 世界じゅうにまたたく間に広がっていきました. これを教訓にして, お 金の流れにも一定のきちんとしたしくみをつくるべきであるといら意見 も強まっています。 p.3 現代社会は国際的な社会だ. なぜなら, 貿易額が年々増加して おり, 国際的な人のゆききも増えているからです。 【図】日本の貿易額の推移(1962年～2008年) p.12 (前略) 冷戦と呼ばれる対立が終わってから, 国々のあいだに貿 易, 技術, 文化などの交流がいっそう進みました. それに輸送手段と の, お金, 情報などが自由にゆきかうようになりました. (中略)こうした 世界の一体化の傾向は, グローバル化とよばれています。

【図】県別人口1万人あたりの外国人登録者と主な都道府県の外国人 登録者の国籍

p.13 グローバル化が進んでも，世界の国々がどこも同じになるとは 考えられません. なぜなら, 同じ言葉を理解する日本のなかにも,さ まざまな地域がそれぞれの特徵を保っているからです.その特徵と は一言でいえば文化です。

【図】国籍別定住外国人推移(1975年～2009年)

p.149 経済のグローバル化によるはげしい競争や産業構造の変化, さらに労働者の高齢化などにともなって, 雇用や賃金のあり方を見直 す企業が増えてきました。

p.188一体化する国際経済:国境のない経済: 1960年代のアメリカ で, 複数の国にまたがって事業を行う, 多国籍企業があらわれまし た. 1985年以降, 日本企業も海外進出を加速させました. (中略) 今日 では, 世界の国々は, たがいを必要とする度合いはますます高まり, 国境をまたぐ地域の動きや市場経済に組み込まれました(グローバル 化).

【図】ユーロ通貨:ユーロの導入により, 為替の取引にともなう障害をな くして貿易や投資活動を活発にしたり，商品の価格の優劣が明らかに なることで企業の競争がうながされたりすると期待されています。

【図】世界の輸出総額の拡大 (1970年〜2008年)

【図】世界の主な経済的な地域統合と日本のFTA・EPA締結相手国 p.189 世界経済の結びつきが強まるにつれ，国と国の貿易に関する 争いが生じます，その解決のために，世界貿易機構(WTO) がありま す.また, 2国間以上で自由貿易協定(FTA)などを結び, 関税などを 削減して, 経済交流を活発にする動きも盛んです。いっぽう, 急速な グローバル化によって, 経済が不安定になったり, 各地域の特徽的な 文化が失われたり寸るおそれがある，といら考え方もあります。 2008年 に起きた世界同時不況は，世界各国の経済に大きな影響をおよぼ し，世界の金融市場が一体化していることを明らかにしました. 先進 国を中心に, 各国が協調して経済の立て直しに取り組んでいます。

【コラム】ブロック経済: 1929年の世界恐慌以降, 帝国主義諸国は, 自 国の産業保護を目的に, 自国と植民地一の関税障壁を高く設けて, 閉鎖的な経済ブロックを形成しました.この結果，それ以外の国々と の貿易は制限され, 経済がいきづまる地域も出て, 第二次世界大戦 の原因の一つになりました. (中略) 現代の地域経済統合は, ブロック 経済の反省を生かして, 地域内の貿易を活発にしつつ, 国際分業に 支えられたグローバル化した世界とも共存できるよう求められていま す.

p.201 国内に資源をもたないわが国は，エネルギー資源の80\%以上 を輸入に頼っています。

p.202【コラム】日本の貿易に関するクイズです，日本は貿易に依存 している国だといわれています. 日本の輸入依存度は約何\%だと思 いますか? 答え $15 \%$. 輸入依存度とは, GDPに対する輸入額の割合 です. 図の国のなかでは, 日本はア耖力に次いで輸入依存度が低 い国です.また，輸出依存度も約16\%です，答えをまちがえた人は， 日本は食料や資源の輸入依存度が高いという知識から, 解答を考え たのではないでしょうか.

【図】国別貿易依存度: 貿易依存度とは, GDPに対する輸出(入)額の 比率です.

【図】わが国の主な農産物の自給率の推移(1960年〜2008年) 【表】金額の食料自給率(1960年から2008年まで5年ごとと2009年) p.6 自由競争のなかで発展してきた世界経済ですが, 近年では, 世 界的な金融危機の影響や，原油や穀物価格の急な值上がりなどによ って大きく摇れ動いています。

版 p.12 わたしたちの暮らしは, 世界とのつながりがなくては成り立ちま
せん.なかでも大きな役割を果たしているのが, 貿易です. (中略)現 在のわたしたちの暮らしは, 一国の経済活動を越えた, 諸外国と相互 に支え合う国際分業の中で営まれているのです. 調和がとれた国際 分業を進めるためには, 各国の間で話し合いをしながら, 一定の調整 や規制をしていく必要があります. しかし, 1980年代以降,さまざまな 規制を緩めて, 企業の自由な活動を拡大させることで, 経済を発展さ せていこうとする動きが世界的に高まりました。

【図】日本の品目別の輸出と輸入の割合

p.13ものやお金を動かし, 情報を発信するのは, 私たち人間です. その人の思いやりや願いが, 国境を越えた先にいる人たちの思いと つながり, しっかりと結びついていかなくては, 調和のとれた国際分 業は成り立ちません. 今後も, 社会のグローバル化が進んでいくなか で, わたしたち一人ひとりが, 世界とつながることの意味を考えていく ことが大切です.

【図】日本の自動車の生産台数と中古車の輸出台数の推移 p.172 1980年代後半から, 国による規制を緩めて, 世界的規模に市 場を拡大しようという考え方が，アメリカなどの先進国を中心に広が り，もの・人・情報·資本が，国境を越えて自由に移動するようになりま した. 市場経済のものでは, なるべく安い労働力や資源で, 効率よく 大きな利益をあげようとするので, 激しい国際競争と世界的な分業が 進められます。白の結果, わたしたちは安い品物を世界各地から入 手できるようになる一方で, 国内でつくられる製品も, 低賃金の外国 人労働者や派遣労働者に依存寸るようになっています. また, 安い労 働力や土地を求めて, 海外に移転する工場も多く, 産業の空洞化が 起こっています.しかし, 各国の経済は, それぞれの自然他社会, 歴 史と結びついて発展してきています. 効率だけを重視する国際的な 競争は, 各国間の, あるいは国内での格差を拡大し, 地域経済や文 化を衰退させ. 社会に混乱を引き起こすなど, さまざまな問題を生じ る可能性があるのです.

【図】穀物・肉類・魚介類の自給率の推移(1970年～2009年)

p.174【コラム】貿易とはなんだろう

そもそもなぜ貿易は行われるのでしようか，その根底には人口，技術 力などの違いがある各国が，それぞれ得意なものを生産したほうが効 率がよいといら，国際分業の考え方があります。 (中略) イギリスのリカ 一ドが唱えた考え方に基づいて, 自由に生産物の交換を行い, 国際 社会全体の利益を増加させようとすることを自由貿易といいます。一 方でこの考え方については, 多くの利益を見込める工業製品を生産 する先進国之, 利益の低い原材料や農産物などを生産する発展途上 国との国際的な役割分担(垂直的分業)を，固定化するという批判もあ ります。つまり，自由貿易では途上国が豊かになるチャンスを得られ ないではないか, といらことです. 19世紀に, 工業化でイギリスに後れ をとっていたドイツでは, 経済学者のリスト(1789〜1846年)が, 国内の 生産力の低い産業を育成して経済発展するためには, 他国の安価な 生産物が大量に流入するのを防ぐべきといら保護貿易を主張し, 自由 貿易に異論を唱えました. ただ,このような輸入制限は, 自国の製品 を国内で売れやすく寸るために, 他国の製品を締め出すこと(ブロッ ク経済)につながり, 各国の対立の原因にもなります. 1930年代, 大不 況を克服するために, 各国はブロック経済圈外の国の生産物の輸入 を制限寸る保護貿易の形成に走り，その対立が第二次世界大戦とい う大きな悲劇につながりました. 大戦の反省に立ち, 戦後の国際社会 は, 国際通貨基金(IMF) や関税及び貿易に関する一般協定 (GATT) を設立し, 自由貿易の拡大に努めました。(中略) 日本の高度経済成 長と現在の豊かな生活の背景には, 戦後10年余りの保護主義的な貿 易政策があったので寸. その後, 円高の進行や石油危機などの国際 情勢の変化にあっても, 日本の輸出額が工業製品を中心に増加し, 世界でも有数の貿易黒字大国となりました. 日本は, 戦後の国際的な 自由貿易促進の恩恵を最も受けた国の一つといえます. (中略)この ように，自由貿易と保護貿易にはそれぞれ長所と短所があり，各国に もそれぞれの事情があるので, WTOの交渉は常に難航しています. ただ，自国ですべてを生産することが不可能である以上，貿易はどの 国にとっても必要不可久なものです. 立場の強い国が自国の利益だ けを強引に追求するのではなく, 先進国と途上国, 工業国と農業国の それぞれがお互いに理解を深め, 国際会議などで粘り強く話し合っ ていくとが求められています。

p.199 現在では, 相互に関税を低く抑える方法しして, 各国が独自に 自由貿易協定(FTA)を結ぶことが多くなっています. 日本では, FTA を発展させた経済連携協定 $(\mathrm{EPA})$ を結ぶことを進めています. 今後 も,こうした国家間のさまざまな経済協力体制は, さらに広がっていく ことが考えられます。 


\section{【図】世界の主な地域統合} 加し, 1968(昭和43)年には国民総生産(GNP)が世界第2位となり，ア 䏚力につぐ経済大国になりました。

p.10 現代の私たちは, 外国とのつながりがなくては生活していけま せん. (中略)このように, 地球全体の時間距離がますます縮まり，つ ながりが強まって一体化しようとする動きをグローバル化といいます. グローバル化が進み，国をこえた交流が増すにつれて，各国は相互 に依存し合う関係になります. 経済では, 貿易などを通じて結びつき が深まっています. 企業によっては, 国際競争力を高めるために, 商 品の企画は自社で行い, 製造は賃金などの低い発展途上国の企業 に発注するといった国際分業を行っています.グローバル化が進む と, 発展途上国の人々にとっては, 働く場所ができたり, 生活が豊か になったりすることもあります.しかし，その恩恵を受けられない国も あり，豊かな国々と貧しい国々との経済格差がますます広がっていき ます。

【図】日本人旅行者・訪日外国人旅行者の推移(1965年～2009年) 【図】日本の海外進出企業の推移と地域別割合(1980年～2007年) p.140（前略)こうした自由な貿易(自由貿易)は，世界中でつくられた 安くてよいものを, 多くの国の消費者の手にいきわたらせることになり ま寸. (中略)グローバル化が進む現代では, 企業にとっては国際競 争がきびしくなりますが, 消費者にとっては生活がより豊かになるとい うこともできます。(中略) 日本ではこうした動きは, 1980年代にはいっ てから急速に広まりました，日本より賃金が低いため, 製造業の企業 も向上をアジア諸国へ移転寸るようになりました. そうなるとそれまで 国内にあった工場は閉され, 働いていた人は職を失います.こうして 国内産業が衰退していくとを産業の空洞化といいます。こうした産業 の空洞化をさけるために，日本の企業は，これまで，ほかの国ではつ くれない品質のよいものや, 新しいものをつくり出してきました. (中 略)これからもこうした強みを生かして, 外国との競争に勝つことが期 待されています。

【図】世界に進出するM社:進出店舗数

【図】日本の輸出入の変化とおもな輸出品(1950年～2009年)

p.144【図】食生活と自給率の変化(1985年度と2009年度)

p.182 現在のEUでは人もお金も自由に行き来することができるように なり,まるで一つの国家ができたようなまとまりが生まれています。(中 略)ただし，国家の壁をのりこえた地域機構は，EUのほかにはまだみ ることができません

育 p.24 世界の国々は, 政治的, 経済的, 文化的, そして環境的にも緊 密に結びつくグローバル化の時代をむかえました. (中略)各国がより 特異な分野の商品を輸出し, 他国から別の商品を輸入することを国際 分業といいます.グローバル化により国際分業が広がり, 各国の間で の自由な貿易 (自由貿易)が活発になりました. しかし, 競争力を高 め，ますます豊かになっている国がある一方で, 貧困から抜け出せな い国も増えています. また，日本のように食料自給率が低く, 海外に 食料を依存している国では，食料を輸出している国が不作になれ ば, たちまちに食料が手に入りにくくなります. 食料を安定して供給す るために，自給率を上げるなどの対策が求められます. そして, グロ 一バル化の経済面では, 資本が国境をこえ, 多国籍企業の活動が大 きくなっているため, 一国の政府での管理が困難になっています. 2008年にアメリカで起こった金融危機は，世界的な不況を引き起こし ました。

【図】輸出入品目の戦前・戦後の比較 $(1934$ 年〜 1936年平均と2010 年)

p.34 日本は高度経済成長期以降，日本製品の品質が世界評価さ れ, 経済の発展をとげました. 一方で, 経済のグローバル化が進むな か, 外国とさまざまな貿易問題が生じることもあり, 国民の経済と生活 をどのように守るかということが, 重要な問題となっています. (中略) 現代の世界は貿易を活発に行うことで，自国で調達できないものや足 りないもの, 効率よく生産できないものなどを補っています. 物を補う ことを安易に輸入にたよりすぎることで, 問題が生じることがあります. 例えば，日本の食料自給率は，供給熱量ベースで約40\%と，先進諸 国の中で特に低い水準です。

【困】おもな国の食料自給率の推移(1961年～2009年)

【図】輸入原材料: 日本の伝統食, 天ぷらそばも輸入食品だらけです. p.126 経済は, 国内の活動だけでなく, 輸出や輸入などを通じて海 外ともつながっています. さらに企業の活動も, 海外で生産し, その 国の人々を雇用するなど, 国境をこえて広がっています. それに応じ
て海外で働く日本人は増加し, 日本国内で働く外国人も増加していま す.また，日本国内の人々が外国の企業の株式を売買したり，日本国 内の企業の株式を外国の人々が売買することも, 最近では, 毎日のよ うに行われています.このように, 経済活動が国境をこえて世界各地 に広がることを, 経済のグローバル化といいます。

【図】海外で生活する日本人の数

p.149 ア归カでの住宅価格の暴落によるサブプライムローンの破綻 をきっかけにして世界規模の経済危機が発生し, 2008年にはア訬力 大手証券会社リーマン・ブラザーズが破たんしました. その影響もあ り，日本経済は2007年秋から景気が後退寸るようになりました，日本 経済は, 加速する少子高齢化の下でどう国際競争力を高めるか，ま た, 2011年3月に起きた東日本大震災の被害から復旧・復興し, 安定 した成長を維持するためにどのような政策を採用すべきか, といら問 題に直面しています。

p.150 今後, 日本経済を成長させていくには, 生産費を下げる技術を 開発・導入するとともに, グローバル化する経済で強い存在感をもつ 新しい商品を次々と開発することなどが重要です。

p.154 グローバル化の進んだ現代社会では, 政治や経済, 文化, 地 球環境などのあらゆる分野で，日本と世界とが強く結びついているこ とを実感します。

p.163 市場やネットワークが国境をこえて広がり，世界に共通の基準 をあてはめようとするグローバル化の流れが強まる中で, 地域的に諸 国が結びつきを強め, 独自性を確保しようという動きです.ヨーロッパ では1993年にヨーロッパ連合 $(\mathrm{EU})$ が発足し, 多くの国が加盟しまし た. 1999年には共通の通貨としてユーロが導入され, 経済面ではひと つの市場として機能しています.

【図】世界各地の地域統合

【図】日本の自由貿易協定と経済連携協定:例えば自由貿易のさまた げとなる関税制度の削減·撤廃などを行います。

p.16 世界はいま, 政治, 経済, 文化などあらゆる面で深く結び付き, グローバル化の時代と呼ばれている. 国境をこえたモノ・カネ・ヒトの 移動はグローバリゼーションともよばれ，世界の国ぐには経済におい すでに一体となっている。

p.17 グローバル化した世界では，異なる文化や最新の技術交流が すすみ, たがいの理解が深まって大きな連帯や協同が生まれてい る.いっぽうで, 経済のグローバル化により, 地球規模での先進国の 多国籍企業間の競争がはげしくなる. その結果, 先進国と発展途上 国, あるいは, それらの企業が進出した国ぐにでの人びとの貧富の差 が拡大している.一国でおこった経済危機が，世界経済を大きくゆさ ぶることもある. 異なる文化の急速な流入は, その国独自の文化を衰 退させ，人びとの反発をまねくかもしれない. また，こんにちの世界に は, 地球環境の保全, 感染症対策, 貧困の削減など, 地球規模で人 びとが協力しあってとりくまなければ解決がむずかしい課題も多い. 国境をこえたひとつの世界を思いえがくのは難しい. けれども，自分 の生活が世界とどのようにつながっているのかは, 知ることができる. 私たちはまず足もとを見つめ, そこから自分の行動を世界に結びつ けていこう.

【図】おもな国の労働人口にしめる外国人の比率

【図】日本における外国人労㗢者数・比率の変化(1995年～2010年) p.120こんにちでは, モノ・ヒト・カネが国境をこえて往来し, 各国の経 済は相互に依存しあい, 世界があたかもひとつの市場のようになりつ つある.このうごきを経済のグローバル化ともいう.

【脚注】このうごきは産業の空洞化ともよばれ，国内の産業の衰退をも たらすとして問題になっている.

p.121 第二次世界大戦後の世界は, 保護貿易やブロック経済圏の形 成による混乱を反省して, 貿易や資本の取り引きを自由化して経済を 発展させようとしてきた。(中略) EUでは, 関税を撤廃して貿易を自由 化したうえに, 資本や労働者の移動を自由にし, 27か国, 約5億人に およぶ巨大なひとつの市場をつくりあげた. さらに通貨の統一を段階 的にすすめている. EUはもつともす寸んだ例であるが, 特定の地域 や国がEPA(経済連携協定)やFTA(自由貿易協定)を結ぶうごきが世 界各地で強まり，モノ・ヒト・カネの自由な移動やサービスなどの連携 の強化がすすめられている. グローバル化によって市場が拡大すれ ば, 安いものが手に入る, 生産の効率がよくなる, 発展途上国に雇用 の機会をもたらす, などが期待される. その反面, 外国産の安い農産 物や工業製品の輸入によって国内の産業が衰えることもある. 自由化 によって利益をえるのは, 世界規模で活躍する先進国の多国籍企業 であるといら理由で, グローバル化に反対するNGOや発展途上国の 人びともいる. グローバル化は今後もさらにすすむだろう. 日本企業 
は競争の激化や進出した国の生産者, 地域住民の生活などにどう対 応していくのだろうか. 相手国の人びとの生活の変化にも視野を広げ て注目していこう。.

【図】世界に進出している日系企業の企業数と従業員数

p.125【コラム】日本と各国とのFTA・EPAの現状: 日本経済にとって, 貿易や投資を自由化し, 人の移動や技術協力を促進することが課題 になっていて, アジア諸国との連携のためのとりくみがす寸んでい る.

p.146【図】日本の食料自給率の変化(1960年～2010年)

p.161【コラム】地域統合のうごき:2002年から流通している共通通貨 のユーロは, 17か国で使われているよ. EUといらひとつの市場として 結束することで, 世界での競争力が高まるんだ.

p.169【図】日本のエネルギーの輸入依存度

自 p.4 グローバル化は, 経済面で最も顕著です. 航空・海上輸送の拡 大とともに，日本には世界中からさまざまなものが輸入されています。 スーパーの食品売り場には, 世界各地から輸入されたさまざまな生鮮 食材が並んでいます. また, 多くの企業が, 海外各地に工場や店や 事務所を開設して, 世界規模で事業を行うようになりました. (中略)し かし, グローバル化した世界で拡大流通するのは, 有益なものだけで はありません. 例えば, 一地方で発生した新型インフルエンザが短期 間で地球全体に広がり, 多数の人が感染し死亡する事態も発生して います。環境破壊とその被害も広域化しています。世界経済の活性 化によって世界中でエネルギー消費が拡大した結果地球温暖化の 加速も指摘されています. また, 2008年にア归カから始まった世界同 時不況にみられるように, 一国で生じた経済危機が瞬時にグローバ ル化するといら問題もあります.さらに, 先進国の文化が他の国々に 流入する例が増大しています. その結果, その国が長い年月をかけ て築いた文化や伝統が失われつつあります. 犯罪も国際化し，増加 するといら事態が生まれ，憂慮されています。

【注釈】グローバル化や情報化が展開しはじめたころには, やがて世 界は一つになり, 国家といら枠組みは不要となる, といら主張もみられ た. しかし現在は, グローバル化や情報化の負の側面が認識され，そ の危険をコントロールすることも国家の新しい役割であると考えられる ようになっている.

p.122 一国内だけで生産し消費する経済活動を営むよりも，世界各 国のあいだで商品を売り買いしたほうが, どこの国にとっても, はるか に豊かな経済生活ができることになります。

【注䣋】わが国の貿易にとっては, 安心して貿易のできる平和な状態 にあること, 各国が他国の製品を締め出寸といった政策(保護貿易) をとらず, 自由に輸出入できる自由貿易体制が維持されることが, 重 要である.

p.180【図】主要国の食料自給率の推移(1965年〜2003年)

付録-5 地方分権の時代だ論に関連する記述内容 p.92【写真】地方公共団体の仕事(消防・水防，上下水道の整備, ご 2の収集, 戸籍の管理 行公体は多くの仕事考行いますが, 従来そのために必 要となるお金の多〈は, 国からの補助にたよってきました. また, 本来 国の仕事であるべきものを，地方公共団体が国の下請け機関のよう にかわりに行うことが多く, 逆に, 地方公共団体が自律的に行うべき仕 事に国が関与することもありました.こうした状況を改めて, それぞれ の地方公共団体が地理的, 社会的, 経済的な特徴に応じた独自の活 動を行えるようにするため, 1999年に地方分権一括法が成立しまし た. それ以降, 国の仕事の多くが地方公共団体の独自の仕事となり, 今でも仕事や財源を国から地方に移寸地方分権が進められていま す. p.92 国(中央政府)と地方公共団体は, 社会の共同生活のための仕 事を分担して行っています. 国は, 国民全体のために, 防衛, 外交, 貨幣の発行, 年金の管理なじを行います. 都道府県は, 一般に市町 警察や公立学校の設置などの仕事を受け持ちます. 市(区)町村は, います。

【写真】地方公共団体の仕事(公園の整備, 消防, 戸籍の登録, 河川 の整備)

【図】地方公共団体の仕事と国の仕事(地方:戸籍や住民登録, ゴミ処 理, 公立学校の設置, 県道や河川の整備, 国民県境保険や介護保険
の運営など 国:外交, 防衛, 貨幣の発行, 国道や河川の整備, 年金 の管理運営など）

p.93 多くの地方公共団体では自由に使える財源が少なく, 不足分は 国からの地方交付税交付金で補われます.また, 道路整備などの公 共事業, 義務教育の実施, 社会保障関係などの特定の仕事について は, 費用の全部または一部が, 国から国庫支出金として, 支払われま す.このような国の補助金は, 公平な公共サービスを国民に保障する ためにある程度必要ですが, 地方の国一の依存心を強めるおそれが あります。

【図】主な都府県の財政収入 (6都府県, 自主財源と依存財源)

【図】地方公共団体の財政支出(都道府県，市町村）

p.95 地域の特徴に応じた政治を行うには, 国が地域の問題にあまり かかわらず, できるだけ地域住民の判断にゆだねるしくみが必要で す.このしくみを地方分権といいます. 2000年に, 地方分権をす寸め る法律 (地方分権一括法)が施行されたことで, 国の仕事の多くが地 方公共団体の独自の仕事となり, 国の関与が減少し, 地方公共団体 はそれまでより自由に活動できるようになりました.

【キーワード】中央集権

地域の問題に国が方針を示したり，大きく関与したり寸るしくみを中央 集権といいます.これまでの国と地方公共団体の関係には, このよう な中央集権的な特徵が残っていました。

p.96 自立した地域とは, 国などに依存しないで, 住民自らの力で地 域を維持している地域のことをいいます。これまでは, 多くの地方公 共団体が, 国に大きく依存していました. しかし, 国の財政状況が悪 化するにつれて, 地方公共団体は, これまでのように国に依存するこ とが難しくなり，自立が求められるようになりました. 現在, 過疎の農村 部から過密の都市部まで, 住民が自ら, 地域の課題に取り組み, 地域 の自立へ向けてけんめいな努力を続けている市町村があります. 農 村部では, 米をレタス, いちごなじ高収入がきたいできる少量多品目 の生産に切りかえ, 成功している地域が少なくありません. シャッター を閉じた商店街が多く,さびれていた商店街でも, 街なみを復活させ て, 商店街を再生し, 地域がにぎわうようになった多くの例がありま す. 都市部でも, 公共機関のバリアフリー, 送迎・移住サービスを充実 させて, 高齢者, 障害者, 子どもにやさしいまちづくりを掲げるととも に, 建物の不燃化・而震化を進め, 避難体制を整備して, 災害に強い まちづくりをしている地域もあります。 (中略)たいせつなことは, 地域 の自立や再生は, 国の政策によるものではなく, 何よりも地域住民の 意欲と土夫にかかっているといらことです。

【キーワード】道州制

日本を数個の大きな単位に再編成し, その各地方に, 自立のための 大きな権限をあたえる制度です。現在は道州制に関する議論が続け られています。 地域によって, 人々が抱える課題や生活への要求も違いま 寸. (中略)さまざまな課題を解決し, 暮らしやすい地域をつくっていく 定が大切です。

p.105 国に権力が集まりすぎると，国民の意思で政治を動かすことが 難しくなってきます. 民主主義の実現のためには, 各地域の課題をで きるだけ地域住民の判断にゆだねていく, 地方分権が望ましいともい われます. 1990年頃になると，大きくなりすぎた国の権限を見直す動 きとともに, 地域の政治が国の下請けとなり, 政府の主導で進められ たてきたことへの批判が強まりました. そのため, 地方分権の制度を 整えることが課題となりました. 1999年には, 地方自治法が大幅に改 正され, 地方が自主的に進められる仕事が拡大しました. この改正を 受けて, 国と地方を「対等・協力」の関係に変え, 地方の権限を強める しくみが整えられるようになってきました.こうして, 住民が独自に工夫 しながら, 身近な地域の政治の取り組む機会が増えてきました。

今, 地域が抱える課題は多様化し，ますます複雑になってきていま す.わたしたち住民自身が，まずは身近な地域の現状を見つめ直し ていくこが必要です。 そこから, 地方分権のこれからの可能性を考 え, 一方で国が行う仕事とのバランスをとりながら, 足りないところを補 っていく方法を考えていくこが大切です。

p.106（地方公共団体の)仕事は, 例えば, 学校や図書館などの設 置, 保健所による住民の健康管理, 上下水道やごみ処理場などの整 備, 消防や交通の取り締まりなど, わたしたちの暮らしのさまざまな面 にわたっています。

【図】地方公共団体の主な仕事: 消防, 上下水道の整備, 戸籍の管 理, 施設の運営

p.107 義務教育の実施や道路・港湾の整備など, 特定の仕事を行う 
目的で, 国から国庫支出金が支払われます. 近年, 地方公共団体の 仕事が増え続けるなかで, 財政難に苦しむところが少なくありませ ん. 地域の実情にあった仕事をするためにも, 特に, 自主財源の確保 が大きな課題となっています。

p.114 独自の政策を実現するには，安定した財源の確保が大きな問 題です. 2007年度からは, 補助金のかわりに, 国が集めた税金の一 部を地方の自主財源に移しかえる税源移譲など, 地方が自由に使え る収入基盤を強める制度も実施されるようになりました。 しかし，依然と して地方の財源不足や, 都市部との間に広がる格差の解消には, 課 題が多く残されていま寸.それぞれの地域が, 財源の確保の工夫と 努力をする一方で, 国は財源に苦しむ地方の声を十分に聞きなが ら, 柔軟な政策を行うことが重要です。

p.171 今日，地方分権が推進され，地域経済のあり方を，地域自身で 決めることが求められています。 しかし，そうした試みが必ずしもうまく いかない例も多く, 地域の実態に見合う活性化の工夫や, 行政と住民 の協力がさらに必要になっています. 今後の地域経済のあり方は, そ こで暮らす人々に大きな影響を与えるとともに，国全体の経済を支え るうえでも重要です。

【図】歳入に占める地方税の割合と地方交付税の割合の比較(上位3 都県と下位3県)

【図】地方財政の借入金の残高とGDPに占める割合の推移 p.62 公共サービスは消防や警察といった住民の安全を守るための 活動功, 道路や上下水道といった生活に必要な社会資本を整備す 万活動, 教育や福祉といった住民の文化的・健康的な生活を維持・向 上させるための活動まで, さまざまな分野で行われています。 【写真】まちはどのような仕事をしている? (空口業務, 消防, 動物園, 夜間急患室)

p.65 適切な地方財政を実現するために, 財源を国から地方一移し, 地方公共団体の歳入を安定させる税源移譲などの財政改革が進めら れています. また, 少子化や不況などの影響もあり, 地方財政の税源 はけっして豊富ではありません. そのため, 地方公共団体は限られた 財源のなかで, 多様化する地域住民の要望にこたえていくために, 歳出の無駄をはぶく努力をしています。

【図】地方公共団体の歳入と歳出

【図】増えている地方公共団体の借金(1985～2008)

p.66 地方公共団体が国の方針に従って政治を行う中央集権から，国 と地方公共団体とが対等の関係で仕事を分担して政治を行う地方分 権へと, 政治のしくみを変えていくことをめざして, 2000 (平成12)年に 地方分権一括法が施行されました. それにより, 各地方公共団体はそ れぞれ独自の判断と責任にもとづき, 地域の実情に会った公共サー ビスを提供していく範囲が大きくなりました。

p.89 現在, 政府の組織を見直寸行政改革や, 国から地方に権限老 移寸地方分権，民間企業にできることは企業に任せる規制緩和など が進められています.これらは, 行政の役割を見直し, 国民の責任と 自発的協力を生か寸「小さな政府」に向けた改革といえますが, 地方 分権と規制緩和をじこまで進めるべきなのか，国会でも意見が分かれ ています 政や政策の権限が集中し寸ぎているといら考え方があります.これを 受けて, 地方に決定権をあたえるため, 中央に権限を集中させている 憲法を改正すべきだしいう意見があります。

p.98【写真】地方公共団体のおもな仕事(消防, 戸籍の管理, ごみの 収集)

p.99 地方公共団体は, 住民のために多くの仕事を行っていま寸. 学 校や図書館, 保育所などの設置や管理, 公園や住宅, 下水道などの 整備, 消防·警察の仕事といった身近なものから, 産業の育成や環境 対策, 福祉の充実など, 私たちの生活に関するあらゆる分野におよ んでいます.また，国が本来果たすべき役割を，地方公共団体が代 わりに行っているものもあります. 旅券の交付や選挙の事務, 道路や 河川の整備, 生活保護などがその例です。

p.100 日本では, 戦前まで, 国の政策が地方まで行きわたるべきだと いら考えから, 都道府県知事も政府から任命され，地方に赴任すると いら中央集権的な手法がとられていました. 戦後, 知事は住民の直接 選挙で選ばれるようになりましたが, 地方行政の仕事の多くは, 国の 仕事を代行することであるなど, 中央と地方が一体となったシステム がとられてきました. このようなシステムは, 戦後の復興から高度成長 一向かう日本にとって, 全国をバランスよく発展させる上で効率的な 一面をもっていました. しかし, 経済大国に成長し, 国際化の時代を
むかえたことから，国は外交や防衛などを重点的に行い，地方にでき ることは可能な限り地方に任せるといら，地方分権の考え方が重視さ れるようになりました. そして, 1995(平成7)年には地方分権推進法が 制定されました. さらに1999(平成11)年には, 国が行うとされていた 多くの仕事が, 地方公共団体に移されるための法律も整備されました (地方分権一括法). (中略)しか儿，不足分のほとんじを国からの支出 に依存しているため, 使いみちについても国の意向に配慮し, 地域 の独自性が出しにくいといら問題があります。 (中略)一方, 財源不足 だけでなく，住民への行政サービスの格差や行政の効率の悪さも地 方公共団体のなやみとなっています. 近年各地では, 地域の能力や 行政の効率を高める方法として, 市町村合併が行われました. (中略) 地域をよくするためには，まずは住民自身が自主的に活動することが 大切です. 地域の共同体は国家の基盤であり, 現在, これらがゆらい でいることが深刻な問題となっています。

【図】地方公共団体の財政支出(都道府県, 市町村)

p.136 政府の支出(財政支出) は, 国と地方公共団体に分けられま 寸. 国の活動は, 国土の保全や開発, 社会保障, 教育や文化の振 興, 防衛など, 全国一律に行われます. また, 地方公共団体の活動に は, 老人介護など地域ごとの福祉や土木施設, 公立学校の運営など があります。

p.74 自分たちのことは自分たちで決めるといら姿勢が大切である.こ のような民主化を目的に制定されたのが地方自治法である。 地方自治には, 国の機関など中央政府への行政権の集中をふせぐ 和たちの音思老行政に反映させることを学習寸 る役割もある. (中略) 地域住民がその地域に必要な政治をみずから おこなうために, 地方公共団体の権限を拡大寸ることが地方分権であ る. 1999年には地方分権一括法が制定され，地方分権化を推進する ために, 国と地方公共団体の役割分担を明確にするとともに，地方公 共団体の権限を拡大して, 住民の要求や地域の特性にあわせた行政 をおこなうしくみをつくることがめざされた. また，地方分権化にともな い,一定の規模の財源や人材が必要になるため, 市町村合併がす寸 められた. しかし，増加するしごとの内容に応じた十分な財源の保障 がないことや, 地域によるサービス内容の格差などが問題となってい る. それぞれの地域に必要な行政を実現するための財源の確保がお おきな課題である。

p.133 住民のさまざまな要望にこたえ, 必要なサービスを効率よく提 供していくには, 国税と地方税の配分を見直したり, 独自の徵税を可 能にしたりするなど, 財源の確保が不可欠である. 地方分権をおしす すめ, 国がおこなっているしごとや権限をできるだけ地方公共団体に 移していくこ方課題となっている.

【図】地方財政の歳入・歳出の内わけ 治体が設置, 運営, 管理を行うものには, 多くは生活関連のもので, 道路, 上下水道, 学校, 図書館, 公園, 病院, 介護・福祉施設, 交通, 警察, 消防, ごみ処理などですが，ほかに，法定受託事務もありま す.

p.104 1995(平成7)年には，それまで国の役割とされてきた権限と業 務の多くを地方公共団体に移寸地方分権推進法が制定されました. 1999年には, 各地方公共団体が特性を生かし，みずからの判断と責 任に基づいて地方行政を行うための地方分権一括法が制定され，国 と地方は対等な関係とされました。

p.105 このように現在, 地方に自立性が求められ, 地方自治体の権 限と責任が大きくなっています. 住民も, 自分たちの地方の行政と財 政に, いっそう積極的な関心をもつことが求められます。

\section{参考文献}

1) 田中皓介, 神田佑亮 : 公共事業を巡る言葉に関するイ メージとその変遷に関する研究，土木学会論文集 F4, Vol.69, No.4, pp.I_1-I_7, 2013.

2) 田中晧介，神田佑亮，藤井聡 : 公共政策に関する大手 新聞社報道についての時系列分析，土木学会論文集 D3, Vol.69, No.5, pp.373-379, 2013.

3) 山岡淳一郎：インフラの呪縛, ちくま新書, 2014.

4) 竹田俊郎：マスメディアと政治, 池田謙一 (編), 政 治行動の社会心理学，北大路書房，pp.26-35， 2001. 
5) 谷口綾子，高野伸栄，加賀屋誠一：心理的 TDM プロ グラム"TFP"の交通・環境教育としての持続的効果, 都市計画学論文集, No.37, pp.265-270, 2002.

6) 土木計画学研究委員会 : モビリティ・マネジメントの 手引き，土木学会，2005.

7)片田敏孝：子どもたちを守った「姿勢の防災教育」, 災害情報，No.10，pp.37-42，2012.

8) 森田康夫 : 新しい中学社会科教科書が描く国土教育の 未来一「失われた 10 年」を取り戻す, 新しい地理教 科書への期待一, JICE REPORT, Vol.23, pp.47-71, 2013.

9) 大石久和 : 国土と日本人, 中公新書, 2012.

10) 文部科学省: 教科書制度の概要, 文部科学省 HP, http://www.mext.go.jp/a_menu/shotou/kyoukasho/gaiyou/0 4060901.html（2014 年 1 月 29 日閲覧）

11) 森美保子, 福島脩美 : 心理臨床におけるナラティヴと 自己に関する研究の動向, 日大心理学研究, 第 3 号, pp.147-167, 2007.

12) 野口裕二:ナラティヴ・アプローチ, 勁草書房, 2009.

13) 藤井聡, 長谷川大貴, 中野剛志, 羽鳥剛史 :「物語」 に関わる人文社会科学の系譜とその公共政策的意義, 土木学会論文集 F5, Vol.67, No.1, pp.32-45, 2011.

14) 藤井聡 : 公共政策論におけるドミナント・ストーリー とオルタナティブストーリー, 土木計画学研究・講演 集, CD-ROM, Vol.43, 2011.

15) 三橋貴明 : 逆説の経済学〜メディア・評論家に歪めら れた真実〜，遊タイム出版，2013.

16) 根津佳樹, 神田佑亮, 小池淳司, 白水靖郎, 藤井聡 : 西日本における国土強勒化インフラ整備による総合 的マクロ効果予測研究，土木学会論文集 F4, Vol.69, No.4, pp.I_57-I_68, 2013.

(2014. 10. 14 受付)

\section{ANALYSIS OF DESCRIPTION ABOUT PUBLIC WORKS ON SCHOOL TEXTBOOKS OF SOCIAL STUDIES IN JUNIOR HIGH SCHOOL}

\section{Kosuke TANAKA, Yusuke KANDA and Satoshi FUJII}

Fundamentally, public policies including public works, infrastructure development aims to build better and more sustainable country. Citizen's adequate understanding on public works is essential in order to proceed desired public works and achieve above the purpose appropriately. It is said that citizen's understandings have strongly influenced on government's decision on public works policy. It seems that school education makes certain influence on common understandings. In such circumstance, analysis of the educational situation over public works is strongly required in order to make adequate common understandings and achieve faster provision of infrastructure. The purpose of this study is to analyze the description contents of textbooks about Social Studies in Junior High school that aim to develop recognition and views on the world. As a result, some textbooks descript public works negatively, and emphasize financial situation worse than current situation. 